\author{
UNIVERSIDADE DE SÃO PAULO \\ FACULDADE DE ODONTOLOGIA DE BAURU
}

RAFAEL CARNEIRO ORTIZ

\begin{abstract}
ALDH1 and CD44 immunoexpression as prognostic indicators of invasion and metastasis in oral squamous cell carcinoma
\end{abstract}





\section{ALDH1 and CD44 immunoexpression as prognostic indicators of invasion and metastasis in oral squamous cell carcinoma}

\section{Immunoexpressão de ALDH1 e CD44 como indicador de prognóstico de invasão e metástase em carcinoma epidermoide de boca}

Dissertação apresentada a Faculdade de Odontologia de Bauru da Universidade de São Paulo para obtenção do título de Mestre em Ciências no Programa de Ciências Odontológicas Aplicadas, na área de concentração Biologia Oral.

Orientadora: Profa. Dra. Camila de Oliveira Rodini Pegoraro. 


\section{Ortiz, Rafael Carneiro}

Or8a ALDH1 and CD44 immunoexpression as prognostic indicators of invasion and metastasis in oral squamous cell carcinoma / Rafael Carneiro Ortiz - Bauru, 2017.

78 p. : il. ; $31 \mathrm{~cm}$.

Dissertação (Mestrado) - Faculdade de Odontologia de Bauru. Universidade de São Paulo

Orientadora: Profa. Dra. Camila de Oliveira Rodini Pegoraro

Autorizo, exclusivamente para fins acadêmicos e científicos, a reprodução total ou parcial desta dissertação/tese, por processos fotocopiadores e outros meios eletrônicos.

Assinatura:

Data:

Comitê de Ética da FOB-USP

CAAE: 50695815.2.0000.5417

DATA: $26 / 11 / 2015$ 
(Cole a cópia de sua folha de aprovação aqui) 



\section{DEDICATÓRIA}

Aos meus irmãos Gustavo e Leandro, por quem detenho todo o amor do mundo. 



\section{AGRADECIMENTOS ESPECIAIS}

A Deus.

À minha orientadora Profa. Dra. Camila de Oliveira Rodini Pegoraro, que me confiou esse trabalho e por quem detenho imenso apreço e carinho. Tenho grande admiração pela sua capacidade cientifica, honestidade, paciência, competência e pela delicadeza e apreço com que cuida de cada um de nós, seus orientados. Agradeço imensamente pela acolhida em seu laboratório e pela oportunidade de aprender muito com este e outros trabalhos.

À minha mãe Conceição Carneiro e às minhas tias Aparecida e Pureza Carneiro. Minha mãe por ter sido fonte de segurança, caráter e honestidade essenciais para minha formação. Por ter dado o máximo de si na nossa criação. Às minhas tias, por todo amor, cuidado e humildade com que me cultivaram durante todos os dias difíceis.

Aos meus irmãos Gustavo e Leandro Ortiz. Vocês me roubaram o tempo dos nossos pais e a minha disposição aos finais de semana, mas em troca eu ganhei o amor de vocês e um grande motivo para ter fé em dias melhores.

Ao Alex Carneiro (in memoriam). Meu querido primo e amado primo, os seus vinte anos estão eternizados na minha história e eu sinto a sua falta todos os dias. Obrigado por me ensinar a amar sem precedentes e a importância de se estar em paz.

Ao meu anjo, Angélica Fonseca. Por todo o senso de companheirismo, dedicação, apreço e amor. Sou grato por ter te conhecido e por te dividido todos os momentos da prova de seleção do mestrado até ... sempre. Obrigado pelas risadas, pelos filmes, pelos chocolates e pela amizade, eu te amo.

À minha querida Claudinha Biguetti. Agradeço por sempre estar disposta em ensinar um pouco do seu vasto conhecimento, por me acolher tão bem e por me pôr a par de tudo. Acima de tudo, agradeço pela amizade que construímos juntos e por ter se tornado minha família, eu te amo. 

Ao meu amigo Franco Cavalla, pelo seu apreço e disponibilidade em me ajudar com quaisquer eventuais dificuldades que apareceram no caminho. Sou grato por todos os momentos divertidos que passamos juntos e orgulhoso em ter aprendido mesmo que um pouco com você. Tenho imenso carinho e admiração por você.

À Profa. Dra. Andreia Espíndola Vieira. Por me acolher tão docemente e com um zelo incrível. Tenho grande admiração pela sua atuação profissional e pessoal, vai ser sempre meu exemplo na pós-graduação de humildade e fé. Agradeço também por todos os momentos de estudo com lâminas histológicas, foram enriquecedores. Estendo meu agradecimento ao seu esposo, Francisnei Ribeiro, por quem também sou grato pelos momentos de preocupação e cuidado. Vocês foram meus pais em Bauru, meu carinho e admiração por vocês ultrapassa a nossa distância física.

À Profa. Dra. Vanessa Soares Lara, por quem tenho intensa admiração e zelo. Agradeço pelas aulas incríveis de Patologia e por ter me acolhido tão bem na FOB-USP. Os seus ensinamentos sempre serão a minha base e incentivo para trilhar todo o meu caminho profissional. 



\section{AGRADECIMENTOS}

Às famílias Carneiro e Ortiz, agradeço por todo amor e incentivo, vocês são a base de tudo.

Aos meus queridos amigos do $3^{\mathbf{0}}$ colegial A - INOC (2009) por todos os momentos felizes que vivemos juntos e por toda compreensão nas inúmeras vezes que não pude estar com vocês.

Aos meus queridos amigos que a graduação me proporcionou Débora Libonato, Roberto Montanholi, Letícia Giacomini, Lucas Leite, Fabiola Deliccio e Vicente Pinheiro Neto. Os nossos dias dourados ficarão para sempre na minha memória e vocês sempre farão parte da minha vida. A vocês, meus sinceros sentimentos de carinho e saudade.

Às minhas queridas amigas que o inglês me proporcionou Jessica Delgado e Lilian Marques, por todos os momentos incríveis que vivemos juntos. Agradeço também a Dayane Manzutti, com quem compartilho uma vida de amizade e que tive a sorte de cursar inglês junto, você é a minha pessoa. Por todas os dias incríveis que cultivamos, expresso aqui o meu amor por vocês.

Aos meus amigos e companheiros de grupo de pesquisa Nádia Amôr e Nathália Martins pelos experimentos e festas compartilhadas, dedico a vocês grande parte do meu carinho e admiração. Estendo meus agradecimentos aos recém-chegados Rodrigo Fonseca e Gabriele Góis.

Aos amigos de outros departamentos que a pós-graduação me proporcionou. Em especial à Mariana Santesso e Cintia Tokurara do departamento de Bioquímica, por todas as vezes que pudemos estar juntos e compartilhar momentos bons, levarei vocês em meu coração por onde quer que eu vá. À minha querida Tuana Medeiros do departamento de Estomatologia, por quem eu desejo toda a felicidade e paz do mundo. Você tem um coração de ouro e um ótimo senso de humor. Obrigado por todas as vezes que nos apoiamos, eu não teria conseguido sem você, te amo. Não menos importante, ao meu amigo e patologista Pepe Burgos, agradeço pelas incríveis noções de patologia que me proporcionou, por toda paciência e por todo companheirismo. Não me falta admiração por você. 

À minha querida amiga e vizinha do Departamento de Estomatologia Lázara Joyce. Por todos os dias que vivemos juntos, por todas as risadas, todas as refeições e todas as reflexões que fizemos juntos. Com você meu coração ficou um "cadinho" mais goiano e maior. Meu carinho, admiração e saudade estarão por todos os meus caminhos. Estendo meu agradecimento à sua mãe Zenaide Oliveira, por todo acolhimento e o todas as marmitas que me proporcionou.

A todos os amigos e companheiros do laboratório de Histologia, FOB - USP que não foram mencionados nos agradecimentos acima. André Petenucci, Bruna Biguetti, Carolina Francisconi, Daniele Pereira, Ever Mena, Jessica Melchiades, Michele Soriani, Paulinha Sanchez, Priscila Colavite, Suelen Paini e Ricardo Arantes. Por todos os momentos de grande aprendizado e diversão que compartilhamos juntos, vocês são incríveis e não me cabem palavras para mensurar o quanto carinho tenho por cada um de vocês. Estendo meu agradecimento aos egressos do laboratório de Histologia que me servem de exemplo e por quem compartilho grande admiração e carinho: Prof. Dr. Carlos Repeke (Cadu) e Profa. Dra. Élcia Silveira.

À querida secretária Teresa, pela sua incrível eficiência e zelo. Obrigado por me receber de uma maneira tão boa e familiar e por todas as vezes que me acolheu em sua casa e convívio social.

Às técnicas do laboratório de Histologia, Danielle Ceollin, Patrícia Germino e Dra. Tânia Cestari. À Patrícia, agradeço especialmente a forma com que conduziu cuidadosamente os procedimentos histológicos desta pesquisa. Agradeço também pela oportunidade de conviver com você e desfrutar da sua incrível companhia e beleza, é impraticável mensurar o quão linda você é de todas as maneiras possíveis. Estendo esse agradecimento à grande Danielle, por quem também carrego grande apreço e admiração. À Dra. Tânia, pelo bom convívio, pelos grandes ensinamentos e apoio durante o mestrado.

Aos professores de Histologia da FOB - USP, Dr. Gerson Francisco de Assis, D. Gustavo Pompermaier Garlet, Dr. Rumio Taga e Dra. Camila Rodini. Agradeço pela carinhosa acolhida no laboratório, por colaborarem para o meu crescimento profissional, por todas as aulas e conselhos incríveis e por todo incentivo diário. Sou grato por toda experiência boa que aprendi com os senhores. 

A Dra. Raquel Ajub Moyses do Departamento de Cirurgia de Cabeça e Pescoço do Hospital das Clinicas da Faculdade de Medicina de São Paulo - USP. Por todo zelo e suporte com que me orientou durante a seleção das amostras no hospital.

Aos demais professores do Departamento de Ciências Biológicas da FOB - USP, pela dedicação com que as contribuições em sala de aula e em laboratório. Agradeço pelo ótimo acolhimento com que me receberam.

Aos Professores e funcionários da FOB - USP, que sanavam com grande cuidado nossas duvidas e necessidades de trabalho. Em especial a Rita (Biblioteca), Letícia (Pósgraduação) Maristela (Comitê de ética) e Profa. Dra. Carla Damante, que sempre tiveram paciência e disponibilidade em me ajudar.

Não menos importante, aos grandes Mestres que lecionaram na minha graduação. Em especial a minha orientadora de pesquisa Ms. Laís Anversa, por me confiar um trabalho lindo e me iniciar na pesquisa cientifica, e por todo suporte que me proporcionou para realização do mesmo. Sempre será um grande exemplo profissional na minha vida. E ao Prof. Marcelo Dainesi, pelas aulas incríveis que nos proporcionou, pela didática perfeita e pelo carinho que me tinha nas aulas. 



\section{AGRADECIMENTOS INSTITUCIONAIS}

À Faculdade de Odontologia de Bauru (FOB) - USP, representada pela digníssima Diretora Profa. Dra. Maria Aparecida de Andrade Moreira Machado.

À Fundação de Amparo à Pesquisa do Estado de São Paulo - FAPESP, processo número 2015/06945-2; pelo apoio financeiro concedido em forma de bolsa, fundamental para realização do mestrado.

À Faculdade de Medicina da USP (FMUSP), em especial ao departamento de cirurgia de cabeça e pescoço. 

Ainda que eu falasse as línguas dos homens e dos anjos ... e ainda que tivesse o dom de profecia, e conhecesse todos os mistérios e toda a ciência, e ainda que tivesse toda a fé, de maneira tal que transportasse os montes, e não tivesse amor, nada seria.

1 Coríntios 13:1,2. 



\section{LIST OF FIGURES}

\section{- FIGURES OF DISSERTATION}

Figure 1 - Models of cellular heterogeneity in solid tumors. Tumors are composed of a heterogeneous population with different phenotypic characteristics. In the figure, different cell phenotypes are shown in different colors; A) stochastic model, in which each cell of the tumor is able to self-renew (curved arrows) and to give rise to new tumors (horizontal arrows), and b) cancer stem cell hypothesis, in which only a subpopulation of tumor cells (cancer stem cells, in yellow) is able to self-renew and originate new tumors

Figure 2 - Schematic view of normal stem cells (A) and cancer stem cells (B). (A) shows different sources of normal SCs, their biological properties of indefinite division by self-renewal and generation of differentiated cells under appropriate conditions; while embryonic stem cells are totipotent, adult stem cells are unipotent but can regain totipotent properties under in vitro conditions, originating the induced pluripotent stem cells (iPSCs). (B) shows that adult epithelial SCs can undergo malignant transformation after cumulative genetic alterations caused by carcinogens, generating CSCs. These CSCs retain the biological properties of self-renewal and generation of differentiated (cancer) cells, leading to cancer development and further metastasis 



\section{- FIGURES OF ARTICLE}

Figure 1 - Representative photomicrographs of the general histopathological characteristics of primary OSCC (A, C and E) and corresponding cervical lymph node metastasis (B, D and F). (A) shows a well-differentiated OSCC with (B) perineural invasion (yellow arrow) and (C) muscle infiltration by tumor cells. (F) reveals extracapsular spread (black arrow) of metastatic cells in cervical lymph node. $\mathrm{H} \& \mathrm{E}$, final magnification of 100x (A and B) and 400x (C-F); OSCC: oral squamous cell carcinoma.

Figure 2 - Representative photomicrographs of ALDH1 and CD44 immunostaining in OSCC primary tumors (A-D) and metastatic lymph nodes (E-H). For primary tumors, focal cytoplasmic ALDH1 staining was observed in central areas of tumor islands (A) and accumulation of ALDH1+ tumor cells around vessels (B) can be seen. High intensity membrane expression of CD44 in tumor cells from peripheral regions of tumor islands $(\mathrm{C})$ and perineural invasion (D) were observed. At metastatic lymph nodes, ALDH1 was labeled in peripheral and central areas of metastasis (E-F). CD44 was widely immunoexpressed in all sites of metastatic lesions (G-H). Final magnification x100 (A, C, E and G) and x400 (B, D, F and H). The graph shows the mean of combined scores ( \pm standard error) in primary tumors and corresponding metastasis for ALDH1 (I) and CD44 (J). OSCC: Oral squamous cell carcinoma

Figure 3 - Cancer-specific survival analysis curve in patients with OSCC with low (black line) or high (red line) expression of ALDH1 and CD44. Five-year survival rates tended to be lower in patients with ALDH1 ${ }^{\text {high }}$ and CD44 ${ }^{\text {low }}$ compared to ALDH1 $1^{\text {low }}$ and CD44 ${ }^{\text {high }}$ immunoexpression compared to ALDH $1^{\text {low }}$, although with no statistical significance $(p=0.1303$ and $P$ 0.3692, respectively). OSCC: oral squamous cell carcinoma. 



\section{LIST OF TABLES}

Table 1 - Scoring system used for evaluation of the CSC markers ALDH1 and CD44 in primary OSCC and corresponding metastatic lymph nodes

Table 2 - Association between demographic, clinical, and pathologic characteristics and protein expression in patients with OSCC and corresponding metastatic lymph nodes 



\section{LIST OF ABREVIATIONS AND ACRONYMS}

CEB

OSSC

HNSCC

$\mathrm{CSC}$

$\mathrm{SC}$

CD44

ALDH1

EMT

TI

FS

$\mathrm{NIH}$

INCA

NOD/SCID

mice

HA

MMP

$\mathrm{ECM}$

ITF
From Portuguese "Carcinoma espidermóide de boca"

Oral Squamous Cell Carcinoma

Head and Neck Squamous Cell Carcinoma

Cancer Stem cells

Stem cells

Principal cell surface receptor for hyaluronate

Aldehyde dehydrogenase 1

Epithelial-mesenchymal transition

Tumor islands

Final score

National Cancer Institute

From Portuguese "Instituto Nacional de Câncer José Gomes Alencar da Silva"

immunodeficient mice with a diabetes-susceptible Non-Obese Diabetic

Hyaluronic acid

Matrix metalloproteinase

Extracellular matrix

Invasive tumor front 



\section{SUMMARY}

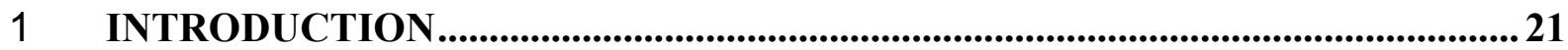

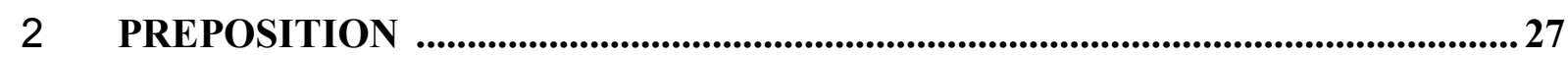

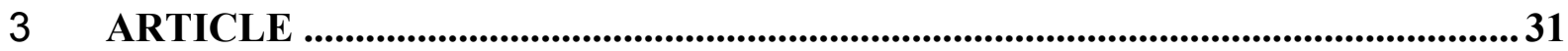

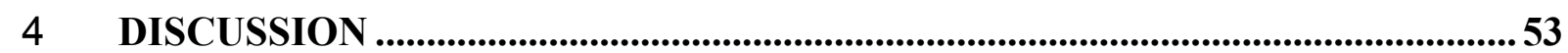

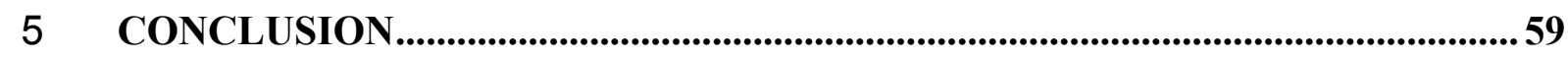

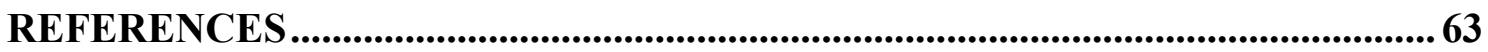

ANNEX 



\begin{abstract}
Oral squamous cell carcinoma (OSCC) is one of the most common cancer in the head and neck and results in high morbidity and mortality annually, being the worst prognosis related to the presence of metastasis in cervical lymph nodes. Metastasis has been associated with a subpopulation of tumor cells, called cancer stem cells (CSCs), which consists of a small population with stem-like cells properties, higher rate of migration and metastatic potential compared to other ordinary tumor cells from the tumor bulk. The aim of present study was to evaluate the immunoexpression of the CSC markers ALDH1 and CD44 in primary sites of OSCC and corresponding metastatic lymph nodes, by means of immunohistochemistry. The immunolabeling was further correlated with clinicopathological data. Archived Formalin-fixed, Paraffin-embedded tumor tissue specimens $(n=50)$ and corresponding metastatic lymph nodes $(\mathrm{n}=25)$ were obtained from 50 patients with OSCC after surgical treatment. CD44 and ALDH1 immunostaining were semi-quantitatively scored according to the proportion and intensity of positive cells within the invasive front and metastatic cervical lymph nodes as a whole. The percentage of ALDH1 and CD44 positive tumor cells as well as immunostaining intensity was graded and a combined score, ranging from 0 to 9 (ALDH1) or 0 to 12 (CD44), was obtained by multiplying both parameters. Next, combined scores were dichotomized into a final score classified as low $(\mathrm{ALDH} 1 \leq 2 ; \mathrm{CD} 44 \leq 4)$ or high $(\mathrm{ALDH} 1>2 ; \mathrm{CD} 44>4)$ immunoexpression. ALDH1 and CD44 immunoexpression was detected in both primary and metastatic tumor sites, although with different immunolabeling pattern. ALDH1-positive tumor cells consisted of scattered patches and no immunoexpression was observed within keratin pearls. Conversely, CD44 immunopositivity was more homogeneous and widely distributed, with higher labeling in peripheral areas of the tumor islands within the tumor invasion front. Although not statistically significant, the means of ALDH $1^{\text {high }}(p=0.0985)$ and CD44 ${ }^{\text {high }}(p=0.1632$; MannWhitney post-test) immunoexpression were higher in metastatic lymph nodes compared to primary tumors. ALDH1 ${ }^{\text {high }}$ was positively associated $(p=0.0184)$ with perivascular invasion, while CD $44^{\text {high }}$ was positively associated ( $p=0.0186$; Fisher's Exact Test) with metastasis $(\mathrm{N}+)$. Five-year survival rates tended to be lower in patients with ALDH1 $1^{\text {high }}$ immunoexpression compared to ALDH $1^{\text {low }}$, although with no statistical significance $(p=0.1303)$. In summary, the present study revealed that CD44 is highly labeled in tumor cell from metastatic sites, being associated with lymph node metastasis, while ALDH1 high immunostaining was associated
\end{abstract}



with perivascular invasion. Altogether, it suggests that immunoexpression of CD44 and ALDH1 links the cancer stem cell phenotype with OSCC invasion and metastasis.

Keywords: Cancer Stem Cells; ALDH1; CD44; Oral Squamous Cell Carcinoma; Cervical metastatic lymph node. 



\section{RESUMO}

O carcinoma epidermóide de boca (CEB) é uma das neoplasias mais comuns da região de cabeça e pescoço e resulta em alta morbidade e mortalidade anualmente, estando o pior prognóstico relacionado à presença de metástase em linfonodos cervicais. O processo de metástase tem sido associado a uma subpopulação de células tumorais, chamadas células-tronco de câncer (CSC, do inglês Cancer stem cells), que consistem em uma pequena população de células com propriedades de células-tronco, incluindo maior taxa de migração e potencial metastático em comparação com outras células tumorais. $\mathrm{O}$ objetivo do presente estudo foi avaliar os marcadores candidatos de CSCs ALDH1 e CD44 em tumores primários de CEB e metástases linfonodais correspondentes, por meio de imuno-histoquímica. A imunomarcação foi posteriormente correlacionada com dados clínico-patológicos. Foram obtidas amostras de tecido tumoral parafinado fixado em formalina $(n=50)$ e os linfonodos metastáticos correspondentes $(n=25)$ de 50 pacientes com CEB submetidos somente ao tratamento cirúrgico. Os marcadores CD44 e ALDH1 foram analisados de forma semi-quantitativa de acordo com a proporção e intensidade de células positivas no fronte de invasão e em linfonodos cervicais metastáticos como um todo. A porcentagem de células tumorais ALDH1 e CD44 positivas, bem como a intensidade da imunomarcação, foi classificada em um escore combinado obtido pela multiplicação de ambos os parâmetros, variando de 0 a 9 (ALDH1) ou 0 a 12 (CD44). Em seguida, as pontuações combinadas foram dicotomizadas em um escore final classificado como baixo (do inglês low) $(\mathrm{ALDH} 1 \leq 2$; CD44 $\leq 4)$ ou alto (do inglês high) $(\mathrm{ALDH} 1>2$; CD44> 4). A imunoexpressão de ALDH1 e CD44 foi detectada tanto em tumores primários quanto em linfonodos cervicais metastáticos, embora com padrão diferente de imunomarcação. Células tumorais ALDH1-positivas foram identificadas como focais e dispersas ao longo do fronte de invasão, sem imunomarcação nas pérolas córneas. Em contraste, a imunopositividade para CD44 foi mais homogênea e amplamente distribuída, com maior imunomarcação em áreas periféricas das ilhotas tumorais presentes no fronte de invasão. Embora não estatisticamente significativa, as médias da imunoexpressão $\operatorname{ALDH} 1^{\text {high }}$ (p = 0.0985) e CD44 ${ }^{\text {high }}$ ( $p=0.1632$, pós-teste de Mann-Whitney) foram maiores em linfonodos metastáticos em comparação com tumores primários. ALDH1 $1^{\text {high }}$ foi positivamente associado com invasão perivascular $(p=0.0184)$, enquanto $C D 44^{\text {high }}$ foi com metástase $(N+)(p=0.0186$; teste exato de Fisher). As taxas de sobrevida global em 5 anos tenderam a ser mais baixas em pacientes com imunoexpressão elevada de ALDH1 em comparação com ALDH1 ${ }^{\text {low }}$, embora 

sem significância estatística $(\mathrm{p}=0.1303)$. Em resumo, o presente estudo revelou que a elevada imunomarcação de CD44 está significativamente associada com metástases linfonodais, enquanto que a elevada imunomarcação de ALDH1 está associada com invasão perivascular. Em conjunto, sugerimos que a imunoexpressão de CD44 e ALDH1 esteja relacionada com o fenótipo de células tronco de câncer que tem capacidade de invasão e metástase em CEB.

Palavras-Chave: Células-tronco de câncer; ALDH1; CD44; Carcinoma epidermóide de boca; linfonodo cervical metastático. 




\section{INTRODUCTION}

Oral squamous cell carcinoma (OSCC) represents the sixth most common cancer worldwide, representing approximately 95\% of head and neck cancers (TORRE et al., 2015). OSSC mainly occurs in men aged 50 years or older (BELCHER et al., 2014) associated with alcohol and tobacco use, and the most frequent anatomical site is tongue and floor of the mouth (FELLER and LEMMER, 2012).

Despite advances in therapeutic research, OSCC still results in high morbidity and mortality, with overall 5-year survival rate still lower than 50\% along the years (CARVALHO et al., 2005; SIEGEL et al., 2014). Worldwide, the National Cancer Institute (NIH) estimates that there will be 49.670 new cases of oral cavity cancer in 2017, and about 9.700 people will die of this disease. In Brazil, the estimative is that 11.140 males and 4.350 females may develop cancer of the oral cavity (INCA, 2016).

Although late diagnosis and local recurrence influence OSCC prognosis badly, the worst prognosis is related to the presence of metastasis in cervical lymph nodes (NOGUTI et al., 2012; PEDERSEN et al., 2016). Therefore, the ability to predict tumor invasiveness and lymph node metastasis based on clinicopathological and immunohistochemical parameters may positively influence the decision on treatment as well as the clinical outcome (JÄRVINEN et al., 2008). The evaluation of lymph node metastases macro and microscopically is already a key point to determine the surgical approach and the possible use of adjuvant chemotherapy in patients with OSSC (OLSEN et al., 2011). A valuable step forward should be the establishment of biomarkers of invasiveness in order to predict metastatic spread and propose a specific treatment protocol. Additionally, the identification of molecules involved in the regulation of biological process of the invasion-metastasis cascade turn possible the translation of the findings into targeted therapy against phenotypically more invasive/metastatic cancer cells.

It is known that mechanisms of tumor recurrence and metastasis, as well as treatment failure, are due, among other factors, to the patterns of cellular heterogeneity present in tumors and two models have been proposed to account for heterogeneity within a tumor. In the clonal evolution model (Figure 1A), all cancer cells accumulated stochastic mutations essentials for adaptation and selection of clones more suitable for the tumor progression; as such, any tumor cell is capable of indefinite proliferation and generating new tumors (WACLAW et al., 2015). 
On the other hand, the model of Cancer stem cells (CSCs) (Figure 1B), hypothesized by Reya et al. in 2001 (REYA et al., 2001), suggests that only a subpopulation of whole tumor cells is available to self-renewal, retaining their features over rounds of cell divisions and to generate a more differentiated progeny, similar to what happens with normal stem cells (CLEVERS, 2011; PLAKS et al., 2015). However, tumor hierarchy is not a one-way route, but can be reversible or plastic, which differentiated cells are able to dedifferentiate and obtain CSC properties under specific conditions (MEDEMA, 2013; MEACHAM; MORRISON, 2013).

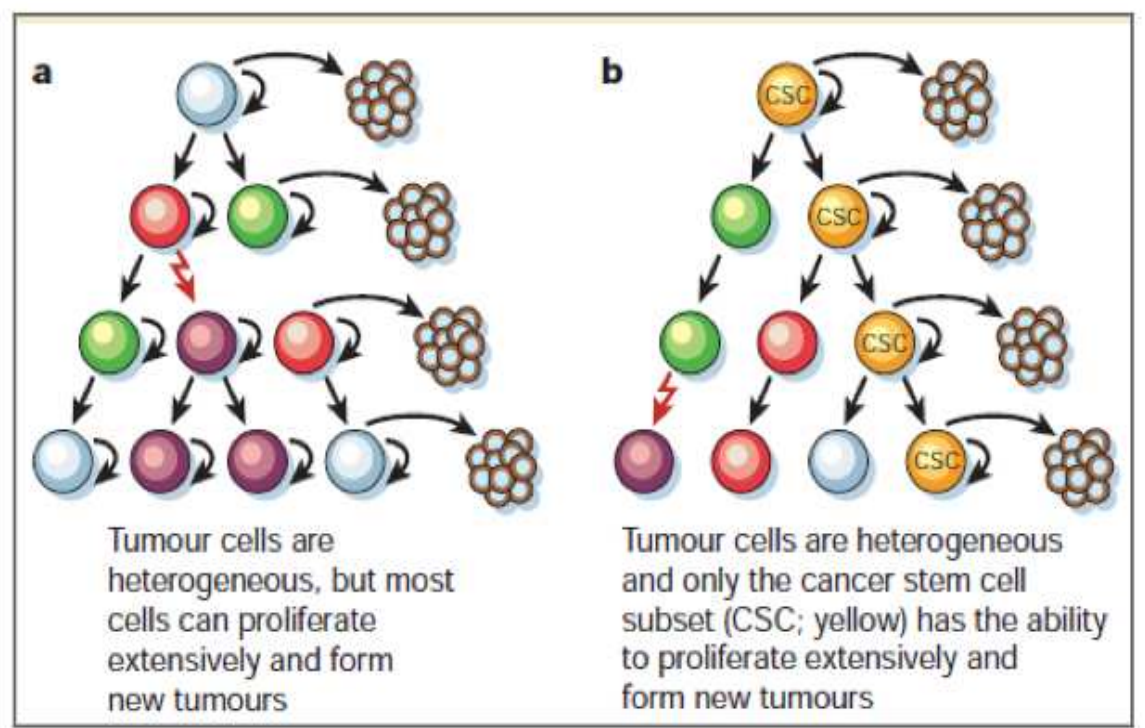

Figure 1. Models of cellular heterogeneity in solid tumors. Tumors are composed of a heterogeneous population with different phenotypic characteristics. In the figure, different cell phenotypes are shown in different colors; (A) stochastic model, in which each cell of the tumor is able to self-renew (curved arrows) and to give rise to new tumors (horizontal arrows), and (B) cancer stem cell hypothesis, in which only a subpopulation of tumor cells (cancer stem cells, in yellow) is able to self-renew and originate new tumors. Retrieved from Reya et al. (2001) (REYA et al., 2001).

As regards to the origin of CSCs, they may be the product of dedifferentiation of somatic cells following oncogenic insult (FRIEDMANN-MORVINSKI and VERMA, 2014) or arise from genetically altered normal stem cells (SC) that lost proliferative control and spatial organization (RODINI et al., 2016). SC are capable of self-renewal and difference in many types of cells; during cell division, SC can generate equal copies of itself and/or differentiate into specialized cells. Normally, they are slowly self-renewing with each cell division producing an average of one stem cell and one what is called a transit-amplifying or progenitor cell, who has limited proliferative potential. However, this number may increase after injury in process of tissue regeneration (BARFOOT et al., 2013). The accumulation of genetic mutations in adult SC could make these cells mutate or dedifferentiate (MENENDEZ et al., 2014) 
producing a CSC, who also are capable to infinity self-renew and generation of differentiated cells (tumor cells) (VERMEULEN et al., 2012). These properties reflect the indefinite growth capacity of tumors, as well as their morphological heterogeneity and several degrees of differentiation (Figure 2).

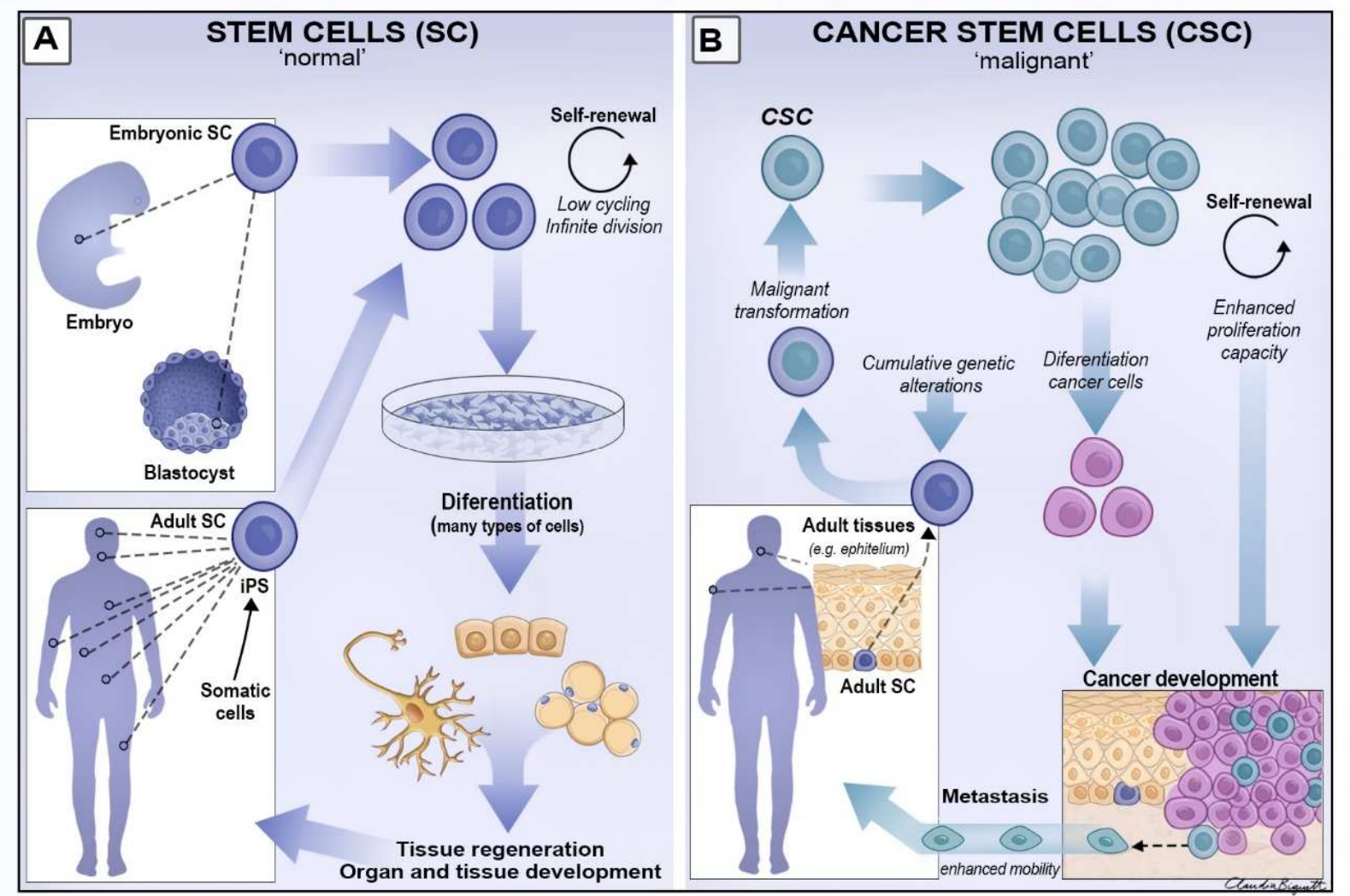

Figure 2. Schematic view of normal stem cells (A) and cancer stem cells (B). (A) shows different sources of normal SCs, their biological properties of indefinite division by self-renewal and generation of differentiated cells under appropriate conditions; while embryonic stem cells are totipotent, adult stem cells are unipotent but can regain totipotent properties under in vitro conditions, originating the induced pluripotent stem cells (iPSCs). (B) shows that adult epithelial SCs can undergo malignant transformation after cumulative genetic alterations caused by carcinogens, generating CSCs. These CSCs retain the biological properties of self-renewal and generation of differentiated (cancer) cells, leading to cancer development and further metastasis. (RODINI et al., 2016, in press).

The concept of CSC has been discussed for years, but the first concrete evidence emerged in 1997 when Bonnet \& Dick (BONNET and DICK, 1997) demonstrated that the ability to initiate tumor growth when leukemic cells were transplanted into NOD/SCID mice was limited to $\mathrm{CD}^{+} 4^{+} / \mathrm{CD} 38^{-}$subpopulation. In solid tumors, Al-Hajj and co-workers (2003: Prospective identification of tumorigenic breast cancer cells. Proc. Natl. Acad. Sci. U.S.A. 100 3983-3988) were the first to demonstrate CSCs in breast cancer using the cellular markers $\mathrm{CD} 44^{+} / \mathrm{CD} 24^{-/ \text {low }} /$ Lineage $^{-}$cells. Later on, Prince and colleagues (2007: Identification of a subpopulation of cells with cancer stem cell properties in head and neck squamous cell carcinoma. Proc. Natl. Acad. Sci. U.S.A. 104 973) were pioneers on identifying a subpopulation 
of head and neck squamous cell carcinoma (HNSCC) tumor cells with stem cell-like phenotypes, initially using the cellular marker CD44 (Prince et al., 2007). Since then, the hypothesis of CSC in HNSCC has been studied extensively (KRISHNAMURTHY and NÖR, 2012). In this regard, several studies have been analyzed the expression of representative CSC markers, such as ALDH1 and CD44 in primary tumors in relation to invasiveness, metastasis, prognosis and therapeutic response (KRISHNAMURTHY and NÖR, 2012; MANNELLI and GALLO, 2012).

One of the most known marker of putative CSC is CD44, a transmembrane glycoprotein and receptor for hyaluronan (HA), widely associated with cell-to-cell adhesion, cell-toextracellular matrix adhesion and interactions, as well as angiogenesis, cell migration and cell proliferation in tumorigenesis (CHINN et al., 2012; BRADSHAW et al., 2016). Also, CD44positive cells have a more primitive, poorly differentiated morphology; therefore, it has been considered a great stem-cell marker (PRINCE et al., 2007). The high expression of CD44 in Head and Neck Cancer, including OSCC, was also associated with poor prognosis and metastasis (CHEN et al., 2014; KOKKO et al., 2011).

For enhancing the applicability of CD44, the association with other markers, such as ALDH1, is necessary. Chinn et al. (2015) demonstrated that the association of CD44 with ALDH1 activity could increase tumorigenesis. Aldehyde dehydrogenase 1 (ALDH1) is from a family of intracellular enzymes involved in cell differentiation, detoxification and drug resistance. It can catalyze the conversion of acetaldehyde to acetic acid and is highly expressed in CSC (KRISHNAMURTHY and NOR, 2012; WU et al., 2015). A number of studies have shown that ALDH1 expression is a well-established marker for normal hematopoietic and nervous system SC, and CSC marker in several types of human cancer, including lung, pancreatic, prostate and head and neck cancers (CLAY et al., 2010; SEINO et al., 2016).

Then, CSC is a subpopulation within tumor mass with remarkable biological properties involved not only with tumor development but also closely related to the process of tumor invasion and metastasis. As such, the aim of present study was to evaluate the immunoexpression of the putative CSC biomarkers CD44 and ALDH1 in primary OSCC and corresponding cervical lymph node metastases. The possible correlation between the expression of the markers and clinicopathological data was also investigated. 
2 PREPOSITION 



\section{PREPOSITION}

The aim of the present study was to evaluate the immunoexpression of the putative CSC markers CD44 and ALDH1 in OSCC primary tumors and corresponding lymph node metastases, by means of immunohistochemistry. Also, in order to elucidate the relationship between the expression of the markers and clinicopathological data, ALDH1 and CD44 immunopositivity level was correlated with parameters such as tumor size (pT), nodal status $(\mathrm{pN})$, perineural invasion, perivascular invasion, histological grade and survival. 

3 ARTICLE 



\section{ARTICLE}

Journal of Oral Pathology \& Medicine.

\section{ALDH1 and CD44 immunoexpression as prognostic indicators of invasion and metastasis in oral squamous cell carcinoma}

Rafael Ortiz ${ }^{1}$, Raquel Ajub Moyses ${ }^{2}$ and Camila Rodini ${ }^{1}$

${ }^{1}$ Department of Biological Sciences, Bauru School of Dentistry, University of São Paulo, Bauru, São Paulo, Brazil; ${ }^{2}$ Department of Head and Neck Surgery, School of Medicine of São Paulo, São Paulo, Brazil

* To whom correspondence should be addressed Camila Rodini, DDS, MSc, PhD, Department of Biological Sciences, Bauru School of Dentistry, University of São Paulo, Av. Otavio Pinheiro Brisolla, 9-75, Jardim Brasil. Tel: +55 149984 02225; Fax: +55 143223 4679; Email: carodini@usp.br

Correspondence may also be addressed to Rafael Ortiz, Tel: +55 14997 470479; Fax: +55 14 3223 4679; Email: rafaelortiz@usp.br

Keywords: Cancer Stem Cells; ALDH1; CD44; Oral Squamous Cell Carcinoma; Cervical metastatic lymph nodes.

Running title: Cancer Stem cell markers in oral carcinoma 


\begin{abstract}
BACKGROUND: Tumor metastasis has been associated with cancer stem cells, a small population with stem-like cells properties, higher rate of migration and metastatic potential compared to tumor cells from the tumor bulk. Our aim was to evaluate the immunoexpression of the putative cancer stem cell biomarkers ALDH1 and CD44 in primary tumor and corresponding lymph node metastases, by means of immunohistochemistry.

METHODS: Tumor tissue specimens $(n=50)$ and corresponding metastatic lymph nodes $(n=25)$ were surgically obtained from 50 patients with oral squamous cell carcinoma. CD44 and ALDH1 were semi-quantitatively scored according to the proportion and intensity of positive cells within the invasive front and metastatic cervical lymph nodes as a whole. A combined score was obtained by multiplying both parameters and later dichotomized into a final score classified as low $(\mathrm{ALDH} 1 \leq 2$; CD44 $\leq 4)$ or high $(\mathrm{ALDH} 1>2$; CD44>4) immunoexpression.
\end{abstract}

RESULTS: ALDH1 and CD44 immunoexpression was detected in both tumor sites, although the means of $\mathrm{ALDH} 1^{\text {high }}(p=0.0985)$ and $\mathrm{CD} 44^{\text {high }}(p=0.1632)$ cells were higher in metastatic lymph nodes compared to primary tumors. ALDH1 ${ }^{\text {high }}$ was positively associated $(p=0.0184)$ with perivascular invasion, while $\mathrm{CD} 44^{\text {high }}$ was positively associated $(p=0.0186)$ with metastasis $(\mathrm{N}+)$. Five-year survival rates tended to be lower in patients with ALDH1 $1^{\text {high }}$ immunoexpression compared to $\operatorname{ALDH} 1^{\text {low }}(p=0.1303)$.

CONCLUSIONS: CD44 highly labeled tumor cells were associated with node metastasis, while ALDH1 high immunostaining was associated with perivascular invasion. Altogether, it suggests that immunoexpression of CD44 and ALDH1 links the cancer stem cell phenotype with oral squamous cell carcinoma invasion and metastasis.

\title{
INTRODUCTION
}

Oral squamous cell carcinoma (OSCC) is one of the most common type of cancer in the head and neck. The worldwide incidence overtakes 300,000 cases and half of them die annually resulting in high morbidity and mortality (1). Despite advances in therapy, the overall 5-year survival rate is $<50 \%$ remaining unaltered over the last decades (2). Although late diagnosis and local recurrence may influence patient survival, the worst prognosis of OSSC is related to metastasis in cervical lymph nodes caused by invasion of cancer cells (3).

Accumulating evidence has shown that recurrence and metastasis are associate with the presence and the maintenance of cancer stem cells (CSCs) (4-7), the most migratory and highly metastatic cellular subpopulation within the tumor. CSCs have characteristics of both cancer 
cells and stem cells, including self-renewal and resistance to apoptosis. It has been suggested that these cells are responsible for tumor progression, once CSCs have higher rate of migration and metastatic potential compared to other ordinary tumor cells (8). Studies have also shown that there is a link between the CSC phenotype and the process of epithelial-mesenchymal transition (EMT), characterized by the loss of cell polarity and cell-cell adhesion, as well as gain of mesenchymal morphology, which allows them to migrate beyond the primary tumor (9).

Importantly, identifying CSCs at routine staining tumor tissues is not possible. It must be based on cell surface markers expression, most of them selected by self-properties involved with tissue development lineage molecules or by hematopoietic or embryonic stem cells (10). The same markers used for CSC isolation have also being studied at the immunohistochemistry level.

The most known marker of CSC is CD44, a transmembrane glycoprotein and receptor for hyaluronan (HA), widely associated with cell adhesion, angiogenesis, cell migration and cell proliferation in tumorigenesis (11-12). It has also been demonstrated that association of CD44 with ALDH1 activity could increase tumorigenesis (13). Aldehyde dehydrogenase 1 (ALDH1), a detoxifying enzyme involved in cell differentiation, detoxification and drug resistance. Is highly expressed in normal and cancer stem cells, including head and neck cancers (14-16).

Positivity for the CD44 has already been investigated in OSCC and correlated with clinical parameters, indicating a higher frequency of CD44-positive cells in patients with local tumor recurrence (23) and also in cervical metastatic lymph nodes (data not published); However, to date there are few studies in the literature about the comparative expression of CSC markers in primary sites of OSCC and corresponding metastatic cervical lymph nodes, as well as their possible clinical significance. In this sense, a recent study investigated the presence of CSC markers in primary tumors and corresponding lymph nodes in head and neck squamous cell carcinoma (HNSCC), demonstrating that there was a high immunoexpression of CD44 in tumor specimens and cultivated cells, as well as a higher frequency of CD44-positive cells in metastatic lymph nodes compared to corresponding primary tumors, emphasizing their importance in tumor progression (24).

Similar study has already been investigated the expression of ALDH1 in OSCC and cervical lymph node metastasis of formalin-fixed and paraffin-embedded tissue blocks and correlated with clinical parameters, indicating a higher frequency of ALDH1-positive cells in in cervical metastatic lymph nodes. Importantly, these results indicate that high expression 
ALDH1 diffuse staining patterns might be novel prediction marker for OSCC lymph node metastasis (22).

Herein, the presence of the CSC biomarkers CD44 and ALDH1 was investigated in OSCC surgical resection specimen of primary tumors and corresponding lymph node metastases, by means of immunohistochemistry. Additionally, the immunoexpression level scored semi-quantitatively was correlated with clinicopathological data and prognosis, aiming to contribute to the understanding of the biological behavior of tumor cells with the capacity for mobility, invasion and dissemination, as well as the its association with the CSC phenotype.

\section{MATHERIAL AND METHODS}

\section{Samples}

Archived Formalin fixed paraffin-embedded primary OSCC from the tongue or floor of mouth $(n=50)$, and corresponding cervical metastatic lymph nodes $(n=25)$, were obtained from the Department of Head and Neck Surgery, Hospital das Clínicas da Faculdade de Medicina da Universidade de São Paulo (HC-FMUSP), São Paulo, Brazil. The study included smoker patients with forty years old or older, with no immune diseases or diabetes, and without any previous treatment before surgical resection. This study was approved by the local Research Ethics Committee of Bauru School of Dentistry (CAAE 50695815.2.0000.54.17) and a signed informed consent was obtained from all participants.

\section{Immunohistochemistry (IHC)}

The immunoexpression of the putative CSC markers ALDH1 and CD44 was analyzed by immunohistochemistry in primary OSCC and cervical lymph nodes metastasis tissue samples. Slides were deparaffinized, rehydrated, and submitted to antigen retrieval in Steamer using citrate-based antigen solution $\mathrm{pH} 6,0$ (Sigma Aldrich) at $95^{\circ} \mathrm{C}$ for $30 \mathrm{~min}$. Sections were then incubated in $3 \%$ hydrogen peroxide for 10 minutes to block endogenous peroxidase activity and with Protein Block Serum-Free (Dako, Carpinteria, CA) for 15 minutes at room temperature to suppress nonspecific binding of subsequent reagents. Tissue sections were incubated for $1 \mathrm{~h}$ at room temperature (RT) with the following primary antibodies: mouse antihuman ALDH1 (clone 44, cat\# 611195, 1:700, BD Biosciences, NJ, USA) and anti-human CD44 (clone 156-3C11, cat\#3570, 1:700, Cell Signalling, MA, USA) monoclonal antibodies. After washing, tissue sections were incubated with biotin-free peroxidase-based ADVANCETM kit (K4068, Dako) visualization system for one hour at RT. Finally, 3'3-diaminobenzidine (DAB) substrate-chromogen system (Dako) was applied for $1 \mathrm{~min}$ and, after washing, sections 
were counterstained with Meyer's haematoxylin. The positive control for immunostaining standardization was either breast cancer cells (ALDH1) or lymphocytes (CD44). Furthermore, negative control was obtained by incubation with $\operatorname{IgG}$ serum in substitution of the primary antibodies. Brown staining in cytoplasm for ALDH1 and membrane for CD44 was considered positive.

\section{Immunostaining quantification}

Immunohistochemical analysis was performed semi-quantitatively by two examiners, under a light microscope (Carl Zeiss) at x400 magnification, blinded to the clinical and pathologic parameters of the samples. The percentage of positive cells as well as the intensity of the immunostaining were scored within the invasive tumor front (ITF - defined as the deepest detached cancer cells or cancer islands) of OSCC and corresponding metastatic cervical lymph nodes as a whole. A combined score was obtained by multiplying percentage and intensity of immunopositivity, ranging from 0 to 9 (ALDH1, modified from Osman, 2014) or 0 to 12 (CD44, modified from Shakib et al., 2015). Table 1 summarizes the scoring system. Finally, combined scores were dichotomized into a final score classified as low $(\mathrm{ALDH} 1 \leq 2$; CD44 $\leq 4)$ or high $(A L D H 1>2 ;$ CD44> 4) immunoexpression.

\section{Statistics}

Statistical analyzes were performed using GraphPad Prism 5 (GraphPad software, Inc., CA, USA). Final scores of ALDH1 and CD44 immunostaining between primary OSCC and corresponding metastatic cervical lymph nodes were compared by Unpaired $\mathrm{T}$ test followed by Mann-Whitney post-test. Correlation between clinicopathological findings and protein immunoexpression was assessed by Fisher's Exact test. Kaplan-Meier and log-rank tests were used to demonstrate and compare survival between different groups. P-values $<0.05$ were considered for statistical significance.

\section{RESULTS}

\section{Sample characterizing}

Most of patients with OSCC were male $(n=40 ; 80 \%)$, smokers $(n=50 ; 100 \%)$ and alcoholist $(\mathrm{n}=50 ; 100 \%)$ aging from 38 to 85 years-old with a mean survival rate of 3.7 years. OSCC lesions are predominantly well- $(n=23 ; 46 \%)$ and moderately- $(n=21 ; 42 \%)$ 
differentiated tumors. The majority of the lesions were classified as T2 $(n=19 ; 38 \%)$ and T4 $(n=12 ; 24 \%)$ and half of the samples were from metastatic tumors $(n=25 ; 50 \%)$. Figure 1 shows representative photomicrographs of well-differentiated primary OSCC and cervical lymph node metastasis.

\section{Immunohistochemical labeling for ALDH1 and CD44}

Semi-quantitative analysis was based on a scoring system considering percentage and intensity of positive cells at the ITF of primary OSCC and corresponding cervical metastatic lymph node as a whole.

Cytoplasmic and membrane labeling were observed for ALDH1 and CD44, respectively, exhibiting a strong and specific immunopositivity in both primary and metastatic tumor sites, although with different immunolabeling pattern. Immunopositivity for ALDH1 revealed scattered patches of positive cells and a notable absence of immunoexpression within keratin pearls. Conversely, CD44 immunopositivity was more homogeneous and widely distributed, with higher labeling in peripheral areas of the tumor islands within the TIF.

Positivity for ALDH1 was observed in 46\% primary OSCC. When ALDH1 positive cells were observed, they were concentrated in focal areas preferably at the center of tumor islands (Fig. 2A and 2B). Conversely, metastatic lymph nodes were predominantly positive for ALDH1 (76\% of the samples), keeping the labeling pattern previously observed in OSCC with sparsely cytoplasmic positivity cells, altrough higher intensity of labbleling was observed in peripheic areas of tumor islands (Tis) (Fig.2E and 2F).

Regarding CD44, tumor cells exhibiting membranous labeling were observed in all primary tumors, but varying according to regions of Tis. Tumor cells from the periphery exhibited high positivity, while a less intensity of labeling was observed in central regions of Tis (Fig. 2C). Interestingly, single CD44-positive cell was found within perineural invasion (Fig. 2D). Tumor stroma was also positive for CD44, mainly in lymphocytes from the peritumoral inflammatory infiltrate (Fig. 2G), and was considered an internal positive control of the immunostaining. Metastatic cevical lymph nodes were totally positive for CD44 (100\% of the samples) and also exbithed a less intensity of labeling in central regions of Tis (Fig. $2 \mathrm{H})$, keeping the labeling pattern observed in OSCC.

Comparing the immunoexpression of the CSC markers in primary sites of OSCC and corresponding cervical lymph node metastasis, the number (mean combined score \pm standard error of mean) of both ALDH1 and CD44-positive cells were higher in metastatic sites (3.80 \pm 0.63 and $7.90 \pm 0.70$ respectively) than in primary tumors $(2.80 \pm 0.50$ and $6.70 \pm 0.53)$ 
respectively, altough without statistical significant $(p=0.0985$ and $p=0.1632$, respectively; Fig. 2I and 2J).

After dichotomization of the immunoexpression, no significant correlation was observed between ALDH1 $1^{\text {low/high }}$ or CD44 $4^{\text {low/high }}$ samples and clinicopathological parameters of age, gender, tumor size (pT), perineural invasion, histological grade and five-years survival. Importantly, ALDH1 $1^{\text {high }}$ immunoexpression was positively associated with perivascular invasion by tumor cells $(p=0.0184)$, while CD44 high was positively associated with cervical lymph node metastasis $(p=0.0186)$ (Table 2$)$.

In general, five-year survival rate was 34\%; from these, the majority of patients exhibited ALDH1 ${ }^{\text {low }}$ and CD44 ${ }^{\text {high }}$ immunoexpression compared to ALDH1 ${ }^{\text {high }}$ and CD44 ${ }^{\text {low }}$, respectively, although these results did not reach statistical significance ( $p=0.1303$ and $p=$ 0.3692, respectively) (Table 2 and Fig. 3).

\section{DISCUSSION}

CSC are considered essential to tumor initiation, maintenance, recurrence and metastasis, and its identification has been proposed as a targeted therapeutic strategy against cancer (19). In this context, studies have shown that CSC can be isolated and enriched by cell surface markers, such as CD44, ALDH1, BMI1, Nanog and Oct4, already identified in various solid tumors $(22,25-27)$. These CSCs markers have also been assessed by immunohistochemistry in primary tumors, being commonly related to metastasis and worse prognosis. In HNSCC, systematic reviews aiming the association of CSC markers and prognostic factors describe relevant information. Chen et al., (2014) showed that CD44 is related to worse T/N category, tumor grade and prognosis. Zhou \& Sun (2014) found that ALDH1-positive HNSCC patients had worse prognosis, which was associated with poorer tumor differentiation, lymph node metastasis, decreased overall and disease-free survival. Fan et al., (2017) reported that high expression of BMI1, Oct-4 and, more importantly, CD133 and Nanog is associated with worse prognosis in HNSCC. It has also been demonstrated that association of CD44 with ALDH1 activity could increase tumorigenesis (20) and is directly related to the CSC phenotype. In the present study, immunoexpression of both ALDH1 and CD44 CSC markers was evaluated on 75 OSCC samples, i.e 50 primary oral squamous cell carcinoma and 25 corresponding metastatic cervical lymph nodes.

ALDH1 immunolabeling was found in $46 \%$ of primary OSCC and $76 \%$ of metastatic lymph nodes. ALDH1-positive tumor cells from primary OSCC were predominantly detected around blood vessels, being significantly correlated with perivascular invasion $(p=0.0184)$. 
Indeed, previous studies with breast (31) and colorectal cancer (21) also associated high expression of ALDH1 with perivascular invasion. Indeed, it is known that ALDH1 activity is associated with EMT program in cancer cells, which contributes to tumor progression and metastasis trough the disruption of basement membrane and invasion into the surrounding microenvironment, such as the lymph and blood vascular systems $(31,33-34)$.

The present results also demonstrated that the percentage and immunostaining intensity (combined score) of ALDH-positive cells were higher in metastatic lymph nodes compared to primary OSCC. This finding is in accordance to Michifuri et al., (2012) who revealed that ALDH1 is associated with high risk of nodal metastasis in OSCC. In face of these, it is reasonable to hypothesize an association between the expression of ALDH1 and the progression of OSCC to cervical lymph nodes.

CD44 CSC marker was positive in all samples of OSCC and metastasis; however, CD44 was more strongly labeled in tumor cells from cervical metastatic lymph nodes than primary tumors. More importantly, CD44 ${ }^{\text {high }}$ immunoexpression was significantly associated with node metastasis $(p=0.0186)$. Similarly, other study in HNSCC have also reported the significant association between high expression of CD44 and cervical lymph node metastasis (32). In this sense, El-aziz et al. (2017) suggest that high expression of CD44 activated some proteinases enzymes, such as matrix metalloproteinase (MMP)-9, which is responsible for digesting extracellular matrix (ECM), thereby promoted the degradation of tumor cell-mediated matrix, resulting in the enhancement of invasion and metastasis. Still, decrease on CD44 expression implies in a reduction or absence of peritumoral stoma binding ability (36), suggesting its role in promoting cervical lymph node metastasis. Additionally, CD44 expression is also associated with poor survival outcomes in OSCC and oropharynx squamous cells carcinoma (35).

Due to the widely labeling observed for CD44 in all our samples (OSCC and cervical metastatic lymph nodes), it was useful to associate ALDH1 as another CSC marker to reach more conclusive findings. Indeed, the importance of CD44 as a CSC-specific marker in HNSCC has been questioned due its expression in normal and neoplastic epithelial cells (37). Thus, the relevance of evaluating the expression of CD44 as a marker of CSC appears to increase when associated with other proteins, such as ALDH1 (38).

Consequently, we also performed a correlation analysis between clinicopathological findings and protein immunoexpression in primary tumors and cervical lymph node metastasis, in order to identify a pattern of ALDH1 and CD44 labeling during tumor progression. Although no statically significant difference was observed here (data not shown), some studies showed that $\mathrm{ALDH}^{+} / \mathrm{CD} 44^{\text {high }}$ cells exhibited increased invasiveness/metastasis potentials both in vitro 
and in vivo. These findings support the notion that the acquisition of CSC-like phenotypes may play a critical role in the metastasis and recurrence of OSCC (39-40).

Regarding survival, no statistically significance difference was found on survival rates associated with ALDH1 or CD44 expression in OSCC. However, five-year survival rate of patients with ALDH1 ${ }^{\text {low }}$ and $\mathrm{CD} 44^{\text {high }}$ immunoexpression was higher compared to ALDH1 ${ }^{\text {high }}$ and CD44 ${ }^{\text {low }}$, respectively ( $p=0.1303$ and $p=0.3692$, respectively). The present results on ALDH1 expression are supported by Habiba et al., (2017); on the other hand, Kokko et al., 2011 observed opposite results than the present on CD44, whose expression was associated with decreased five-year survival. In face of some contradictory results and the absence of statistical significance in some comparisons, two limitations of the present study to be considered are the sample size and the intrinsically limitations of score analysis.

In conclusion, our study demonstrated that CD44 ${ }^{\text {high }}$ cells were associated with cervical lymph node metastasis while ALDH1 ${ }^{\text {high }}$ was associated with perivascular invasion, both considered important parameters for OSCC poor prognosis. Altogether, the present findings suggest that immunoexpression of CD44 and ALDH1 links the cancer stem cell phenotype with OSCC invasion and metastasis.

\section{Acknowledgements}

The authors are grateful to Fundação de Amparo à Pesquisa do Estado de São Paulo — FAPESP and Coordenação de Aperfeiçoamento de Pessoal de Nível Superior-CAPES.

\section{Conflict of interests}

The authors declare no conflict of interests. 


\section{REFERENCES}

1. Torre LA, Bray F, Siegel RL, Ferlay J, Lortet-Tieulent J, Jemal A. Global cancer statistics, 2012. CA Cancer J Clin. 2015; 65: 87108.

2. Oh MS, Kang SH, Kim HJ, et al. Overall five-year survival rate in squamous cell carcinoma of oral cavity. J Korean Assoc Oral Maxillofac Surg. 2009; 35:83 88.

3. Pedersen L, Idorn M, Olofsson GH, et al. Voluntary Running Suppresses Tumor Growth through Epinephrine- and IL-6-Dependent NK Cell Mobilization and Redistribution. Cell Metab. 2016; 23: 55462.

4. M. Shackleton. Normal stem cells and cancer stem cells: similar and different. Semin. Cancer Biol. 2010; 20: 8592

5. Ebben, JD, Treisman DM, Zorniak M, et al. The cancer stem cell paradigm: a new understanding of tumor development and treatment. Expert Opin. Ther. 2010; 14: 621 632.

6. Visvader JE. Cells of origin in cancer. Nat. 2011; 469: 314322.

7. H. Clevers. The cancer stem cell: premises, promises and challenges. Nat. Med. 2011; 17: 313319 .

8. Yu Z, Pestell TG, Lisanti MP, Pestell RG. Cancer stem cells. Int. J. Biochem. Cell Biol. 2012; 44: 21442151.

9. De Craene B, Berx G. Regulatory networks defining EMT during cancer initiation and progression. Nature Rev. Cancer. 2013; 13: 97110.

10. Mărgăritescu D, Pirici D, Simionescu C, Stepan A. The utility of CD44, CD117 and CD133 in identification of cancer stem cells (CSC) in oral squamous cell carcinomas (OSCC). Rom J Morphol Embryol. 2011; 52: 985993.

11. Huang CF, Xu XR, Wu TF, Sun ZJ, Zhang WF. Correlation of ALDH1, CD44, OCT4 and SOX2 in tongue squamous cell carcinoma and their association with disease progression and prognosis. J Oral Pathol Med. 2014; 43: 4928.

12. Bradshaw A, Wickremsekera A, Tan ST, Peng L, Davis PF, Itinteang T. Cancer stem cell hierarchy in glioblastoma multiforme. Front Surg. 2016; 21: 115.

13. Chinn SB, Darr OA, Owen JH, et al. Cancer stem cells: mediators of tumorigenesis and metastasis in head and neck squamous cell carcinoma. Head Neck. 2015; 37: 31726.

14. Krishnamurthy S, Nor JE. Head and neck cancer stem cells. J Dent. Res. 2012; 91: 334 40. 
15. Wu S, Xue W, Huang X, et al. Distinct prognostic values of ALDH1 isoenzymes in breast cancer. Tumour Biol. 2015; 36: 24212426.

16. Seino S, Shigeishi H, Hashikata M, et al. CD44(high)/ ALDH1(high) head and neck squamous cell carcinoma cells exhibit mesenchymal characteristics and GSK3betadependent cancer stem cell properties. J Oral Pathol Med. 2016; 45: 180188.

17. Osman TA. Cancer Stem Cell-Related Markers in Normal and Neoplastic Oral Mucosa. A study on human samples and experimental models. Bergen. Thesis. University of Begen. 2014.

18. Shakib PA, Ensani F, Abdirad A, Valizadeh B, Seyedmajidi M, Sum S. CD44 and CD74: The promising candidates for molecular targeted therapy in oral squamous cell carcinoma. Dent Res J (Isfahan). 2015; 12: 1816.

19. Nassar D, Blanpain C. Cancer Stem Cells: Basic Concepts and Therapeutic Implications. Annu. Rev. Pathol. 2016; 11: 4776.

20. Kendall K, Repp MR, Jilka T, Kingsley K. Biomarker screening of oral cancer cell clines revealed sub-populations of CD133-, CD44-, CD24- and ALDH1-positive cancer stem cells. J Cancer Res Ther. 2013; 1: 111118.

21. Holah NS, Aiad HA, Asaad NY, et al. Evaluation of the Role of ALDH1 as Cancer Stem Cell Marker in Colorectal Carcinoma: An Immunohistochemical Study. J Clin Diagn Res. 2017; 11: EC17 EC23.

22. Michifuri Y, Hirohashi Y, Torigoe T, et al. High expression of ALDH1 and SOX2 diffuse staining pattern of oral squamous cell carcinomas correlates to lymph node metastasis. Pathol Int. 2012; 62: 6849.

23. Joshua B1, Kaplan MJ, Doweck I, Pai R, Weissman IL, Prince ME, Ailles LE. Frequency of cells expressing CD44, a head and neck cancer stem cell marker: correlation with tumor aggressiveness. Head Neck. 2012; 34: 4249.

24. Mannelli G, Magnelli L, Deganello A, Busoni M, Meccariello G, Parrinello G, Gallo O. Detection of putative stem cell markers, CD44/CD133, in primary and lymph node metastases in head and neck squamous cell carcinomas. A preliminary immunohistochemical and in vitro study. Clin Otolaryngol. 2015; 40: 31220.

25. Qian X, Chenming M, Nie X, et al. Biology and immunology of cancer stem(-like) cells in head and neck cancer. Crit Rev Oncol Hematol 2015; 95: 337345.

26. Patel SS, Shah KA, Shah MJ, et al. Cancer Stem Cells and Stemness Markers in Oral Squamous Cell Carcinomas. Asian Pac J Cancer Prev 2014; 15: 85498556. 
27. Satpute PS, Hazarey V, Ahmed R, et al. Cancer Stem Cells in Head and Neck Squamous Cell Carcinoma: A Review. Asian Pac J Cancer Prev 2013; 14: 5795587.

28. Chen J, Zhou J, Lu J, et al. Significance of CD44 expression in head and neck cancer: a systemic review and meta-analysis. BMC Cancer 2014; 14: 15.

29. Zhou C, Sun B. The prognostic role of the cancer stem cell marker aldehyde dehydrogenase 1 in head and neck squamous cell carcinomas: a meta-analysis. Oral Oncol 2014; 50: 1144-1148.

30. Fan Z, Li M, Chen X, et al. Prognostic Value of Cancer Stem Cell Markers in Head and Neck Squamous Cell Carcinoma: a Meta-analysis. Sci Rep. 2017; 7: 43008.

31. Kitamura H, Torigoe T, Hirohashi Y, et al. Prognostic impact of the expression of ALDH1 and SOX2 in urothelial cancer of the upper urinary tract. Mod Pathol. 2013; 26: 11724 .

32. Sun DY, Yu H, Qiu XB, et al. Relationships between CD44, hyaluronic acid expression and lymphatic metastasis and radiosensitivity of nasopharyngeal carcinoma. Biomed Res 2016; 27: 286291.

33. Ueda K, Ogasawara S, Akiba J, et al. Aldehyde dehydrogenase 1 identifies cells with cancer stem cell-like properties in a human renal cell carcinoma cell line. PloS One. 2013; 8: e754 63.

34. Chen J, Xia Q, Jiang B, et al. Prognostic Value of Cancer Stem Cell Marker ALDH1 Expression in Colorectal Cancer: A Systematic Review and Meta-Analysis. PloS One. 2015; 10: e0145 164 .

35. De Moraes FP, Lourenço SV, Ianez RC, et al. Expression of stem cell markers in oral cavity and oropharynx squamous cell carcinoma. Oral Surg. Oral Med. Oral Pathol. Oral Radiol. 2017; 123: 113-122.

36. Umeda T, Ishida M, Murata S, et al. Immunohistochemical analyses of CD44 variant isoforms in invasive micropapillary carcinoma of the breast: comparison with a concurrent conventional invasive carcinoma of no special type component. Breast Cancer 2015; 23: 869875.

37. Mack B and Gires O. CD44s and CD44v6 expression in head and neck epithelia. PloS ONE 2008; 3: e3360.

38. Koukourakis MI, Giatromanolaki A, Tsakmaki V, et al. Cancer stem cell phenotype relates to radio-chemotherapy outcome in locally advanced squamous cell head-neck cancer. Br J Cancer 2012; 106: 846853. 
39. Zang S, Liu T, Shi J, Qiao L. Curcumin: a promising agent targeting cancer stem cells. Anticancer Agents Med Chem. 2014; 14: 78792.

40. Wang P, Gao Q, Suo Z, et al. Identification and characterization of cells with cancer stem cell properties in human primary lung cancer cell lines. PloS One 2013; 8: e57020.

41. Habiba U, Hida K, Kitamura T, et al. ALDH1 and podoplanin expression patterns predict the risk of malignant transformation in oral leukoplakia. Oncol Lett. 2017; 13: 321328.

42. Kokko LL, Hurme S, Maula SM, et al. Significance of site-specific prognosis of cancer stem cell marker CD44 in head and neck squamous-cell carcinoma. Oral Oncol 2011; 47: 510516.

43. El-Aziz YSA, Megahed EME, Mostafa WAE, et al. Role of CD44 and cortactin in metastasis of oral squamous cell carcinoma. Tanta Dent J 2017; 14: 6267. 


\section{LIST OF TABLES}

Table 1. Scoring system used for evaluation of the CSC markers ALDH1 and CD44 in primary OSCC and corresponding metastatic lymph nodes.

\begin{tabular}{ccccc}
\hline \multicolumn{2}{c}{ ALDH1 } & \multicolumn{3}{c}{ CD44 } \\
\hline Score & Percentage & Intensity & Percentage & Intensity \\
\hline $\mathbf{0}$ & $<5 \%$ & Negative & - & Negative \\
$\mathbf{1}$ & $5-25 \%$ & Weak & $0-10 \%$ & Weak \\
$\mathbf{2}$ & $26-49 \%$ & Moderate & $11-25 \%$ & Moderate \\
$\mathbf{3}$ & $\geq 50 \%$ & Strong & $26-49 \%$ & Strong \\
$\mathbf{4}$ & - & - & $\geq 50 \%$ & - \\
\hline
\end{tabular}

Table 2. Association between demographic, clinical, and pathologic characteristics and protein expression in patients with OSCC and corresponding metastatic lymph nodes.

\begin{tabular}{|c|c|c|c|c|c|c|c|}
\hline \multirow[b]{2}{*}{ Characteristic } & \multicolumn{4}{|c|}{$A L D H 1$} & \multicolumn{3}{|c|}{ CD44 } \\
\hline & Category & Low $n(\%)$ & $\begin{array}{c}\text { High } n \\
(\%)\end{array}$ & $P$ & Low $n(\%)$ & High n (\%) & $P$ \\
\hline \multirow{2}{*}{ Age } & $<60$ & $21(42.0 \%)$ & $10(20.0 \%)$ & \multirow{2}{*}{0.3716} & $10(20.0 \%)$ & $21 \quad(42.0 \%)$ & \multirow{2}{*}{0.3716} \\
\hline & $\geq 60$ & $10(20.0 \%)$ & $9(18.0 \%)$ & & $9(18.0 \%)$ & $10 \quad(20.0 \%)$ & \\
\hline \multirow{2}{*}{ Gender } & Female & $6(12.0 \%)$ & $4(8.0 \%)$ & \multirow{2}{*}{1.000} & $4(8.0 \%)$ & $6 \quad(12.0 \%)$ & \multirow{2}{*}{1.000} \\
\hline & Male & $25(50.0 \%)$ & $15(30.0 \%)$ & & $15(30.0 \%)$ & $25 \quad(50.0 \%)$ & \\
\hline \multirow{2}{*}{ T category } & $T 1 / T 2$ & $18(36.0 \%)$ & $10(20.0 \%)$ & \multirow{2}{*}{0.7742} & $12(24.0 \%)$ & $17 \quad(34.0 \%)$ & \multirow{2}{*}{0.7780} \\
\hline & $T 3 / T 4$ & $13(26.0 \%)$ & $9(18.0 \%)$ & & $8(16.0 \%)$ & $14 \quad(28.0 \%)$ & \\
\hline \multirow{2}{*}{ N category } & NO & $17(34.0 \%)$ & $8(16.0 \%)$ & \multirow{2}{*}{0.7742} & $14(28.0 \%)$ & $11 \quad(22.0 \%)$ & \multirow{2}{*}{$0.0186^{*}$} \\
\hline & $N+$ & $14(28.0 \%)$ & $11(22.0 \%)$ & & $5(10.0 \%)$ & $20 \quad(40.0 \%)$ & \\
\hline \multirow{2}{*}{$\begin{array}{c}\text { Perineural } \\
\text { invasion }\end{array}$} & Yes & $23(46.0 \%)$ & $11(22.0 \%)$ & \multirow{2}{*}{0.3493} & $12(24.0 \%)$ & $21 \quad(42.0 \%)$ & \multirow{2}{*}{0.7667} \\
\hline & No & $8(16.0 \%)$ & $8(16.0 \%)$ & & $7(14.0 \%)$ & $10 \quad(20.0 \%)$ & \\
\hline \multirow{2}{*}{$\begin{array}{l}\text { Perivascular } \\
\text { invasion }\end{array}$} & Yes & $1(2.0 \%)$ & $5(10.0 \%)$ & \multirow{2}{*}{$0.0184^{*}$} & $0 \quad 0(0 \%)$ & $5 \quad(10.0 \%)$ & \multirow{2}{*}{0.1424} \\
\hline & No & $31(62.0 \%)$ & $13(26.0 \%)$ & & $19(38.0 \%)$ & $26 \quad(52.0 \%)$ & \\
\hline \multirow{3}{*}{$\begin{array}{c}\text { Histological } \\
\text { grade }\end{array}$} & Well & $13(26.0 \%)$ & $10(20.0 \%)$ & \multirow{3}{*}{0.1236} & $10(20.0 \%)$ & $12(24.0 \%)$ & \multirow{3}{*}{0.3753} \\
\hline & Moderately & $y 16(32.0 \%)$ & $5(10.0 \%)$ & & $6(12.0 \%)$ & $16 \quad(32.0 \%)$ & \\
\hline & Poorly & $2(4.0 \%)$ & $4(8.0 \%)$ & & $3(6.0 \%)$ & $(6.0 \%)$ & \\
\hline \multirow{2}{*}{ Survival } & $<5$ years & $18(36.0 \%)$ & $15(30.0 \%)$ & \multirow{2}{*}{0.1303} & $14(28.0 \%)$ & $19 \quad(38.0 \%)$ & \multirow{2}{*}{0.3692} \\
\hline & $\geq 5$ years & $13(26.0 \%)$ & $4(8.0 \%)$ & & $5(10.0 \%)$ & $12 \quad(24.0 \%)$ & \\
\hline
\end{tabular}




\section{LIST OF FIGURES}
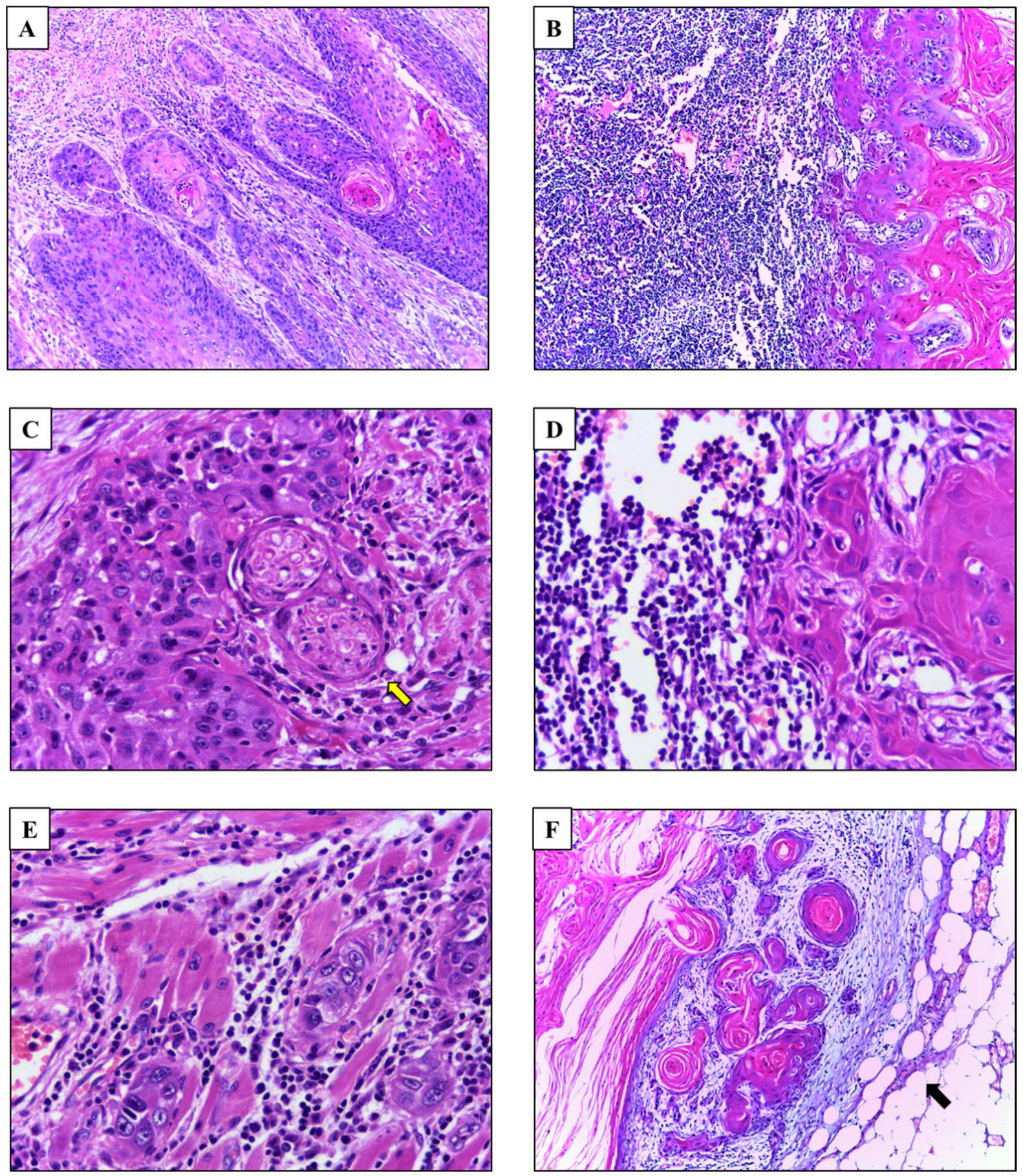

Figure 1 

ALDH1

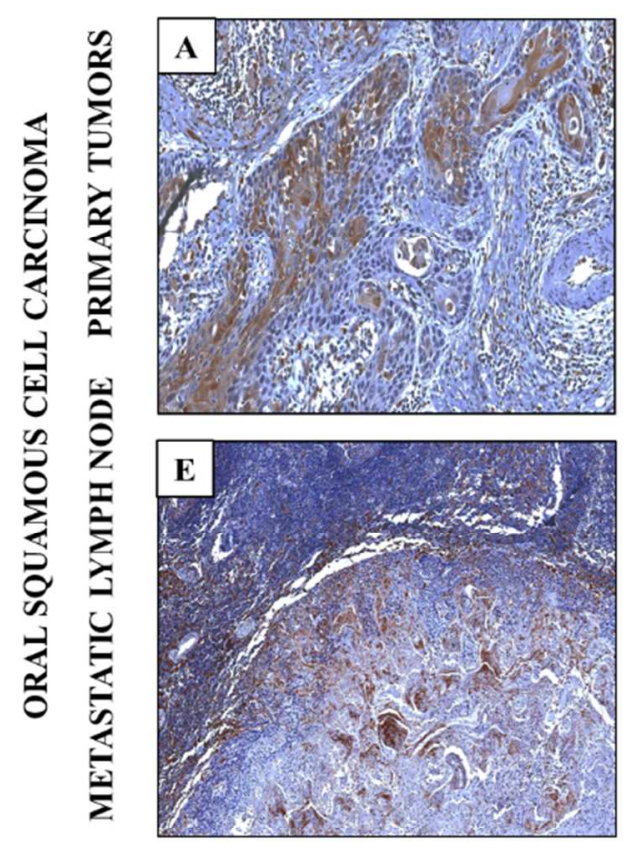

I

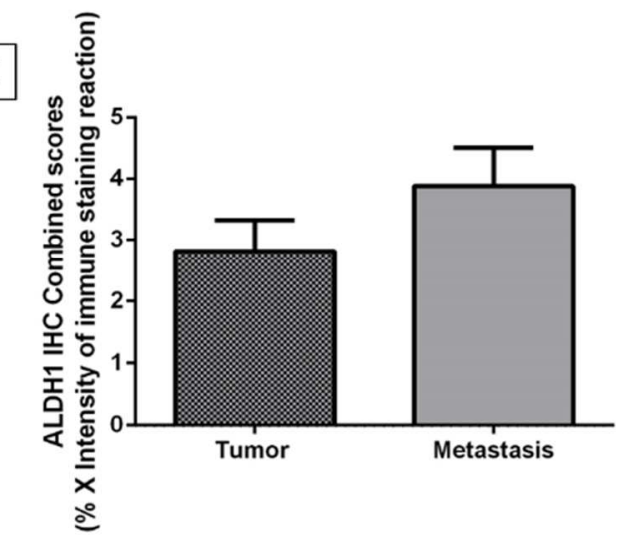

CD44
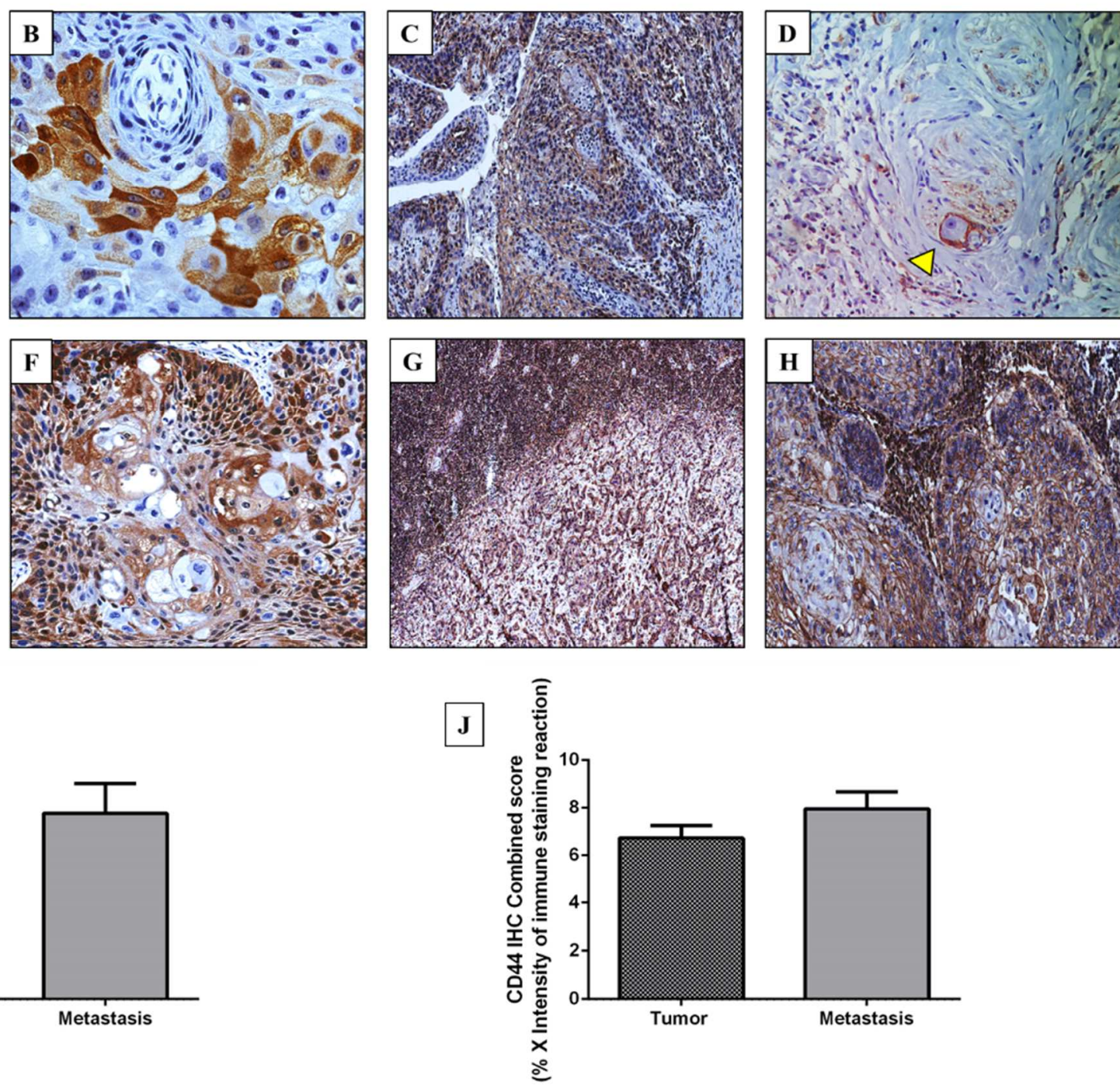

Figure 2 


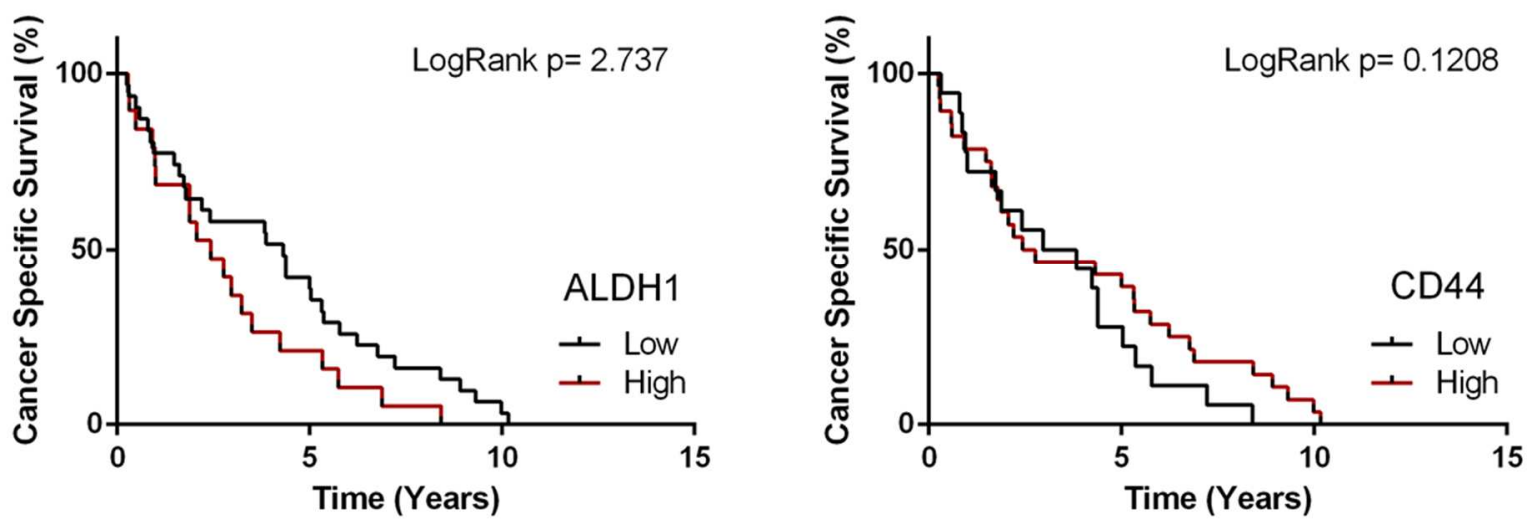

Figure 3 


\section{LIST OF FIGURE LEGENDS}

Figure 1. Representative photomicrographs of the general histopathological characteristics of primary OSCC (A, C and E) and corresponding cervical lymph node metastasis (B, D and F). (A) shows a well-differentiated OSCC with (B) perineural invasion (yellow arrow) and (C) muscle infiltration by tumor cells. (F) reveals extracapsular spread (black arrow) of metastatic cells in cervical lymph node. H\&E, final magnification of 100x (A and B) and 400x (C-F); OSCC: oral squamous cell carcinoma.

Figure 2. Representative photomicrographs of ALDH1 and CD44 immunostaining in OSCC primary tumors (A-D) and metastatic lymph nodes (E-H). For primary tumors, focal cytoplasmic ALDH1 staining was observed in central areas of tumor islands (A) and accumulation of ALDH1+ tumor cells around vessels (B) can be seen. High intensity membrane expression of CD44 in tumor cells from peripheral regions of tumor islands (C) and perineural invasion (D) were observed. At metastatic lymph nodes, ALDH1 was labeled in peripheral and central areas of metastasis (E-F). CD44 was widely immunoexpressed in all sites of metastatic lesions (G-H). Final magnification x100 (A, C, E and G) and x400 (B, D, F and H). The graph shows the mean of combined scores ( \pm standard error) in primary tumors and corresponding metastasis for ALDH1 (I) and CD44 (J). OSCC: Oral squamous cell carcinoma

Figure 3. Cancer-specific survival analysis curve in patients with OSCC with low (black line) or high (red line) expression of ALDH1 and CD44. Five-year survival rates tended to be lower in patients with $\mathrm{ALDH} 1^{\text {high }}$ and $\mathrm{CD} 44^{\text {low }}$ compared to ALDH1 ${ }^{\text {low }}$ and $\mathrm{CD} 44^{\text {high }}$ immunoexpression compared to ALDH $1^{\text {low }}$, although with no statistical significance $(\mathrm{p}=$ 0.1303 and P 0.3692 , respectively). OSCC: oral squamous cell carcinoma. 



\section{DISCUSSION}

OSCC is a multifactorial disease, which poor prognosis is associated with cervical lymph node metastasis (FERLAY et al., 2015). Metastasis consists in a complex multistep biological process in which cancer cells lose adhesion to their neighboring cells and invade the surrounding tissue; they reach the blood stream and further interact with the endothelium of distant organs where they overflow and establish micro metastasis. Once in the new site, the cancer cells restart proliferation programs originating the macro and detectable metastases (SCHROEDER et al., 2011).

Although the exact mechanism that confers tumor cells the capacity to break free from the primary lesions and invade adjacent tissues are not completely understood, innumerous studies have suggested the epithelial-to-mesenchymal transition (EMT) as key factor in this first step of the metastatic cascade (RHIM et al., 2012; TSAI et al., 2012; YU et al., 2013). Furthermore, EMT is associated with increased cell motility and resistance to chemotherapy (De CRAENE and BERX, 2013).

In addition, recent works have associated stem-cell phenotype of cancer cells as predictor for invasion and consequently metastasis (PANG et al., 2010; BACCELLI \& TRUMPP, 2012) and experimental activation of EMT confers many of the properties of CSCs in epithelial carcinoma cells (MANI et al., 2008; MOREL et al., 2008). Over recent years, cell surface markers for CSC phenotype were determined for breast, brain, colon, pancreas, lung, liver, and for head and neck cancers (VISVADER and LINDEMAN, 2008).

The use of CSC markers has been implicated as a useful tool in clinicopathological characterization and its association with patient's prognosis justified the intensive effort in the identification of specific CSC markers in different cancers, such as recent studies in pancreatic ductal adenocarcinoma (DURKO et al., 2017) and lung cancer (ROUDI et al., 2014).

These CSCs markers have also been assessed by immunohistochemistry in primary tumors, being commonly related to metastasis and worse prognosis. In head and neck cancer squamous cell carcinoma (HNSCC), systematic reviews aiming the association of CSC markers and prognostic factors describe relevant information. Chen et al., (2014) showed that CD44 is related to worse T/N category, tumor grade and prognosis. Zhou \& Sun (2014) found that 
ALDH1-positive HNSCC patients had worse prognosis, which was associated with poorer tumor differentiation, lymph node metastasis, decreased overall and disease-free survival. Fan et al., (2017) reported that high expression of BMI1, Oct-4 and, more importantly, CD133 and Nanog is associated with worse prognosis in HNSCC. It has also been demonstrated that association of CD44 with ALDH1 activity could increase tumorigenesis (KENDALL et al., 2013) and is directly related to the CSC phenotype. In the present study, immunoexpression of both ALDH1 and CD44 CSC markers was evaluated on 75 OSCC samples, i.e 50 primary oral squamous cell carcinoma and 25 corresponding metastatic cervical lymph nodes.

Importantly, numerous molecular events of significance for tumor spread, such as gain and loss of adhesion molecules, secretion of proteolytic enzymes, increased cell proliferation, and initiation of angiogenesis occur at the tumor-host interface or invasive front (BRYNE, 1998; BANKFALVI and PIFFKO, 2000). The invasive tumor front (ITF) it is defined as the deepest tumor islands or detached cells, specifically the three to six more invasive tumor cells at the advancing edge of the OSCCs (PIFFKO et al., 1997). Thus, in many different types of carcinomas, cancer cells at the ITF of the primary tumor frequently exhibit signs of EMT activation, including the reduced expression of $\mathrm{E} \square$ cadherin, secretion of proteolytic enzymes, increased cell proliferation and initiation of angiogenesis (SHARMA et al., 2013), favoring tumor invasion and consequently, the formation of metastasis. Therefore, it is reasonable to assume that the best value prognostic information about the tumor invasive cells can be identify in the ITF, where presumably most aggressive cells reside (WELKOBORSKY et al., 1999; BANKFALVI and PIFFKO, 2000). Although several studies have been reported the prognostic significance of ITF in OSCC (KUROKAWA et al., 2005; MOHTASHAM et al., 2013; PEREIRA et al., 2016) no study have assessed the expression of CSC markers ALDH1 and CD44 in this area and compared to cervical lymph node metastasis.

The present results demonstrated that the percentage and immunostaining intensity (combined score) of ALDH-positive cells were significantly higher in metastatic lymph nodes compared to primary OSCC. This finding is in accordance to Michifuri et al., (2012) who revealed that ALDH1 is associated with high risk of nodal metastasis in OSCC. In face of these findings, it is reasonable to hypothesize an association between the expression of ALDH1 and the progression of OSCC to cervical lymph nodes.

CD44 CSC marker was positive in all samples of OSCC and metastasis; however, it was more strongly labeled in tumor cells from cervical metastatic lymph nodes than primary tumors. 
More importantly, CD44 ${ }^{\text {high }}$ immunoexpression was significantly associated with node metastasis $(p=0.0186)$. Similarly, other study in HNSCC have also reported the significant association between high expression of CD44 and cervical lymph node metastasis (SUN et al., 2016). El-aziz et al. (2017) suggest that high expression of CD44 activated some proteinases enzymes, such as matrix metalloproteinase (MMP)-9, which is responsible for digesting extracellular matrix (ECM), thereby promoted the degradation of tumor cell-mediated matrix, resulting in the enhancement of invasion and metastasis. Still, decrease on CD44 expression implies in a reduction or absence of peritumoral stoma binding ability (UMEDA et al., 2015), suggesting its role in promoting cervical lymph node metastasis. Additionally, CD44 expression is also associated with poor survival outcomes in OSCC and oropharynx squamous cells carcinoma (De MORAES et al., 2017).

Due to the widely labeling observed for CD44 in all our samples (OSCC and cervical metastatic lymph nodes), it was useful to associate ALDH1 as another CSC marker to reach more conclusive findings. Indeed, the importance of CD44 as a CSC-specific marker in HNSCC has been questioned due its expression in normal and neoplastic epithelial cells (MACK and GIRES, 2008). Thus, the relevance of evaluating the expression of CD44 as a marker of CSC appears to increase when associated with other proteins, such as ALDH1 (KOUKOURAKIS et al., 2012).

In many circumstances, multiple immunohistochemistry (IHQ) can be a powerful tool in both diagnostics and research. Osman et al. (2014) observed that patients with OSCC have different CSC-related marker profile, which co-expression of p75NTR and ALDH1A1 is probably related to different aspects during OSCC progression. Thus, we also want to perform a multiple IHQ to validate our findings associated with other CSC markers, such as BMI1.

We also performed a correlation analysis between clinicopathological findings and protein immunoexpression in primary tumors and cervical lymph node metastasis, in order to identify a pattern of ALDH1 and CD44 labeling during tumor progression. Although no statically significant difference was observed (data not shown), some studies showed that $\mathrm{ALDH}^{+} / \mathrm{CD}_{4} 4^{\text {high }}$ cells exhibited increased invasiveness/metastasis potentials both in vitro and in vivo. These findings support the notion that the acquisition of CSC-like phenotypes may play a critical role in the metastasis and recurrence of OSCC (WANG et al., 2013; ZANG et al., 2014). 
No statistically significance difference was found on survival rates associated with ALDH1 or CD44 expression in OSCC. However, five-year survival rate of patients with $\mathrm{ALDH} 1^{\text {low }}$ and $\mathrm{CD} 44^{\text {high }}$ immunoexpression was higher compared to ALDH $1^{\text {high }}$ and $\mathrm{CD} 44^{\text {low }}$, respectively ( $p=0.1303$ and $p=0.3692$, respectively). The present results on ALDH1 expression are supported by Habiba et al., (2017); on the other hand, Kokko et al., 2011 observed opposite results: CD44 expression was associated with decreased five-year survival. In face of some contradictory results and the absence of statistical significance in some comparisons, two limitations of the present study to be considered are the sample size and the intrinsically limitations of score analysis.

In conclusion, our study demonstrated that CD $44^{\text {high }}$ cells were associated with cervical lymph node metastasis while ALDH1 $1^{\text {high }}$ was associated with perivascular invasion, both considered important parameters for OSCC poor prognosis. Altogether, the present findings suggest that immunoexpression of CD44 and ALDH1 links the cancer stem cell phenotype with OSCC invasion and metastasis. 
5 CONCLUSIONS 



\section{CONCLUSIONS}

Our study demonstrates that high expression of ALDH1 was associated with perivascular invasion, while high expression of CD44 was associated with nodal metastases. It suggests that ALDH1 and CD44 putative CSCs markers might be associated with OSCC progression and metastasis to cervical lymph nodes due to the ability of vascular invasion and colonization of metastatic sites. This would then represent a link between the cancer stem cell phenotype and invasion and metastasis of OSCC. 

REFERENCES 



\section{REFERENCES}

Baccelli, I. \& Trumpp, A. The evolving concept of cancer and metastasis stem cells. J. Cell Biol. 2012;198:281-293.

Bankfalvi A, Piffko J. Prognostic and predictive factors in oral cancer: The role of invasive tumor front. J Oral Pathol Med. 2000;29:291-8.

Barfoot, J. et al. Stem Cell Research: Trends and Perspectives on the Evolving International Landscape. EuroStemCell and Kyoto University's Institute for Integrated Cell-Material Sciences (WPI-iCeMS) 2013;p.73.

Belcher R, Hayes K, Fedewa S, Chen AY. Current treatment of head and neck squamous cell cancer. J Surg Oncol. 2014;110:551-574.

Bonnet D, Dick JE. Human acute myeloid leukemia is organized as a hierarchy that originates from a primitive hematopoietic cell. Nat Med. 1997;3:730-7.

Bradshaw A, Wickremsekera A, Tan ST, Peng L, Davis PF, Itinteang T. Cancer stem cell hierarchy in glioblastoma multiforme. Front Surg. 2016;3(21):1-15.

Carvalho AL, Nishimoto IN, Califano JA, Kowalski LP. Trends in incidence and prognosis for head and neck cancer in the United States: a site-specific analysis of the SEER database. Int J Cancer. 2005;114(5):806-16.

Chen J, Zhou J, Lu J, Xiong H, Shi X, Gong L. Significance of CD44 expression in head and neck cancer: a systemic review and meta-analysis. BMC Cancer. 2014;14:15.

Chen L, Bourguignon LY. Hyaluronan-CD44 interaction promotes c-Jun signaling and miRNA21 expression leading to Bcl-2 expression and chemoresistance in breast cancer cells. Mol Cancer. 2014;13:52.

Chinn SB, Darr OA, Owen JH, Bellile E, McHugh JB, Spector ME, Papagerakis SM, Chepeha DB, Bradford CR, Carey TE, Prince ME. Cancer stem cells: mediators of tumorigenesis and metastasis in head and neck squamous cell carcinoma. Head Neck 2015;37:317-26.

Chinn SB, Darr OA, Peters RD, Prince ME. The role of head and neck squamous cell carcinoma cancer stem cells in tumorigenesis, metastasis, and treatment failure. Front Endocrinol 2012;3:90. 
Clay MR, Tabor M, Owen JH, Carey TE, Bradford CR, Wolf GT, Wicha MS, Prince ME: Single-marker identification of head and neck squamous cell carcinoma cancer stem cells with aldehyde dehydrogenase. Head Neck 2010;32:1195-1201.

Clevers H. The cancer stem cell: premises, promises and challenges. Nat Med. 2011;17:313319.

De Craene B, Berx G. Regulatory networks defining EMT during cancer initiation and progression.Nat Rev Cancer 2013;13:97-110.

De Moraes FP, Lourenço SV, Ianez RC, de Sousa EA, Silva MM, Damascena AS, Kowalski LP, Soares FA, Coutinho-Camillo CM. Expression of stem cell markers in oral cavity and oropharynx squamous cell carcinoma. Oral Surg. Oral Med. Oral Pathol. Oral Radiol. 2017; 123:113-122.

Durko L, Wlodarski W, Stasikowska-Kanicka O, Wagrowska-Danilewicz M, Danilewicz M, Hogendorf P, Strzelczyk J, Malecka-Panas E. Expression and Clinical Significance of Cancer Stem Cell Markers CD24, CD44, and CD133 in Pancreatic Ductal Adenocarcinoma and Chronic Pancreatitis. Dis Markers. 2017; 2017:3276806.

El-Aziz YSA, Megahed EME, Mostafa WAE, Iman Ezzo IM. Role of CD44 and cortactin in metastasis of oral squamous cell carcinoma. Tanta Dent J 2017;14:62-67.

Fan Z, Li M, Chen X, Wang J, Liang X, Wang H, Wang Z, Cheng B, Xia J. Prognostic Value of Cancer Stem Cell Markers in Head and Neck Squamous Cell Carcinoma: a Meta-analysis. Sci Rep. 2017; 7: 43008.

Feller L, Lemmer J. Oral squamous cell carcinoma: epidemiology, clinical presentation, and treatment. J Cancer Ther. 2012;3:263-268.

Ferlay J, Soerjomataram I, Dikshit R, Eser S, Mathers C, Rebelo M, Parkin DM, Forman D, Bray F. Cancer incidence and mortality worldwide: Sources, methods and major patterns in GLOBOCAN 2012. Int J Cancer. 2015;136:E359-86.

Friedmann-Morvinski D, Verma IM. Dedifferentiation and reprogramming: origins of cancer stem cells. EMBO Rep 2014; 15: 244-5310.

Gabbert H, Wagner R, Moll R, Gerharz CD. Tumor dedifferentiation: an important step in tumor invasion. Exp. Metastasis 1985;3:257-279. 
Habiba U, Hida K, Kitamura T, Matsuda AY, Higashino F, Ito YM, Ohiro Y, Totsuka Y, Shindoh M. ALDH1 and podoplanin expression patterns predict the risk of malignant transformation in oral leukoplakia. Oncol Lett. 2017; 13: 321328.

Instituto Nacional do Câncer (BR). Estimativa 2016: incidência do câncer no Brasil. Rio de Janeiro: INCA;2016.

Järvinen AK, Autio R, Kilpinen S, Saarela M, Leivo I, Grenman R, Makitie AA, Monni O. High-resolution copy number and gene expression microarray analyses of head and neck squamous cell carcinoma cell lines of tongue and larynx. Genes Chromosomes Cancer 2008;47:500-509.

Kendall K, Repp MR, Jilka T, Kingsley K. Biomarker screening of oral cancer cell clines revealed sub-populations of CD133-, CD44-, CD24- and ALDH1-positive cancer stem cells. J Cancer Res Ther. 2013;1:111-118.

Kokko LL, Hurme S, Maula SM, Alanen K, Grenman R, Kinnunen I, Ventela S. Significance of site-specific prognosis of cancer stem cell marker CD44 in head and neck squamous-cell carcinoma. Oral Oncol. 2011;47(6):510-516.

Koukourakis MI, Giatromanolaki A, Tsakmaki V, Danielidis V, Sivridis E. Cancer stem cell phenotype relates to radio-chemotherapy outcome in locally advanced squamous cell headneck cancer. Br J Cancer 2012;106:846-853.

Krishnamurthy S, Nor JE. Head and neck cancer stem cells. J Dent. Res. 2012;91(4):334-40.

Kurokawa H, Zhang M, Matsumoto S, Yamashita Y, Tanaka T, Tomoyose T, Takano H, Funaki K, Fukuyama H, Takahashi T, Sakoda S. The relationship of the histologic grade at the deep invasive front and the expression of Ki-67 antigen and p53 protein in oral squamous cell carcinoma. J Oral Pathol Med. 2005;34:602-7.

Mack B, Gires O. CD44s and CD44v6 expression in head and neck epithelia. PLoS ONE 2008;3:e3360.

Mani SA, Guo W, Liao MJ, Eaton EN, Ayyanan A, Zhou AY, Brooks M, Reinhard F, Zhang CC, Shipitsin M, Campbell LL, Polyak K, Brisken C, Yang J, Weinberg RA. The epithelialmesenchymal transition generates cells with properties of stem cells. Cell. 2008;133(4):704-15.

Mannelli G, Gallo, O. Cancer stem cells hypothesis and stem cells in head and neck cancers. Cancer Treat Rev. 2012;38:515-539. 
Meacham CE, Morrison SJ. Tumour heterogeneity and cancer cell plasticity. Nature. 2013;501:328-37.

Medema JP. Cancer stem cells: the challenges ahead. Nat. Cell Biol. 2013;15:338-44.

Menendez JA, Alarcón T, Corominas-Faja B, Cuyàs E, López-Bonet E, Martin AG, Vellon L. Reprogramming the epigenetic landscapes of patient-derived cancer genomes. Cell Cycle. $2014 ; 13: 358-370$.

Menendez JA, Alarcón T. Metabostemness: A new cancer hallmark. Front Oncol. 2014;4:262.

Michifuri Y, Hirohashi Y, Torigoe T, Miyazaki A, Kobayashi J, Sasaki T, Fujino J, Asanuma H, Tamura Y, Nakamori K, Hasegawa T, Hiratsuka H, Sato N. High expression of ALDH1 and SOX2 diffuse staining pattern of oral squamous cell carcinomas correlates to lymph node metastasis. Pathol Int. 2012;62:684-9.

Mohtasham N, Babakoohi S, Shiva A, Shadman A, Kamyab-Hesari K, Shakeri MT, SharifiSistani N. Immunohistochemical study of p53, Ki-67, MMP-2 and MMP-9 expression at invasive front of squamous cell and verrucous carcinoma in oral cavity. Pathol Res Pract. 2013;209:110-114.

Morel AP,1 Lièvre M, Thomas C, Hinkal G, Ansieau S, Puisieux A. Generation of Breast Cancer Stem Cells through Epithelial-Mesenchymal Transition. PLoS ONE 2008;3:e2888.

Noguti J, De Moura CF, De Jesus GP, Da Silva VH, Hossaka TA, Oshima CT, Ribeiro DA. Metastasis from oral cancer: an overview. Cancer Genomics Proteomics. 2012;9(5):329-335.

Olsen SM, Moore EJ, Koch CA, Kasperbauer JL, Olsen KD. Oral cavity and oropharynx squamous cell carcinoma with metastasis to the parotid lymph nodes. Oral Oncol. 2011;47:142144.

Pang R, Law WL, Chu AC, Poon JT, Lam CS, Chow AK, Ng L, Cheung LW, Lan XR, Lan HY, Tan VP, Yau TC, Poon RT, Wong BC. A subpopulation of CD26+ cancer stem cells with metastatic capacity in human colorectal cancer. Cell Stem Cell 2010;6:603-615.

Pedersen NJ, Jensen DH, Hedback N, Frendo M, Kiss K, Lelkaitis G, Mortensen J, Christensen A, Specht L and von Buchwald C. Staging of early lymph node metastases with the sentinel lymph node technique and predictive factors in T1/T2 oral cavity cancer: A retrospective singlecenter study. Head Neck. 2016;38:E1033-1040.

Pereira CH, Morais MO, Martins AF, Soares MQ, Alencar RC, Batista AC, Leles CR, Mendonça EF. Expression of adhesion proteins (E-cadherin and $\beta$-catenin) and cell 
proliferation (Ki-67) at the invasive tumor front in conventional oral squamous cell and basaloid squamous cell carcinomas. Arch Oral Biol. 2016;61:8-15.

Piffko J, Bánkfalvi A, Ofner D, Rasch D, Joos U, Schmid KW. Standardized demonstration of silver-stained nucleolar organizer regions-associated proteins in archival oral squamous cell carcinomas and adjacent non-neoplastic mucosa. Mod Pathol. 1997;10:98-104.

Plaks V, Kong N, Werb Z. The cancer stem cell niche: how essential is the niche in regulating stemness of tumor cells? Cell Stem Cell. 2015;16:225-38.

Prince ME, Sivanandan R, Kaczorowski A, Wolf GT, Kaplan MJ, Dalerba P, Weissman IL, Clarke MF, Ailles LE. Identification of a subpopulation of cells with cancer stem cell properties in head and neck squamous cell carcinoma. Proc. Natl. Acad. Sci. 2007;104:973-978.

Reya T, Morrison SJ, Clarke MF, Weissman IL. Stem cells, cancer, and cancer stem cells. Nature 2001;414:105-111.

Rhim AD, Mirek ET, Aiello NM, Maitra A, Bailey JM, McAllister F, Reichert M, Beatty GL, Rustgi AK, Vonderheide RH, Leach SD, Stanger BZ. EMT and dissemination precede pancreatic tumor formation. Cell. 2012;20;14849-61.

Rodini Co, Lopes NM, Lara VS, Mackenzie I. Oral cancer stem cells - properties and consequences. J Appl Oral Sci - in press.

Roudi R, Madjd Z, Korourian A, Mehrazma M, Molanae S, Sabet MN, Shariftabrizi A. Clinical significance of putative cancer stem cell marker CD44 in different histological subtypes of lung cancer. Cancer Biomark 2014;14:457-467.

Schroeder A, Heller DA, Winslow MM, Dahlman JE, Pratt GW, Langer R, Jacks T, Anderson DG. Treating metastatic cancer with nanotechnology. Nat. Rev. Cancer, 2011;12:39-50.

Seino S, Shigeishi H, Hashikata M, Higashikawa K, Tobiume K, Uetsuki R, Ishida Y, Sasaki K, Naruse T, Rahman MZ, Ono S, Simasue H, Ohta K, Sugiyama M, Takechi M. CD44(high)/ ALDH1(high) head and neck squamous cell carcinoma cells exhibit mesenchymal characteristics and GSK3betadependent cancer stem cell properties. J Oral Pathol Med 2016;45(3):180-188.

Sharma M, Sah P, Sharma SS and Radhakrishnan R: Molecular changes in invasive front of oral cancer. J Oral Maxillofac Pathol. 2013;17:240-247.

Siegel R, Ma J, Zou Z, Jemal A. Cancer statistics, 2014. CA Cancer J Clin. 2014;64(1):9-29. 
Sun DY, Yu H, Qiu XB, Li G, Zhang N. Relationships between CD44, hyaluronic acid expression and lymphatic metastasis and radiosensitivity of nasopharyngeal carcinoma. Biomed Res 2016;27(2):286-291.

Torre LA, Bray F, Siegel RL, Ferlay J, Lortet-Tieulent J, Jemal A. Global cancer statistics, 2012. CA Cancer J Clin. 2015;65:87-108.

Tsai JH, Donaher JL, Murphy DA, Chau, S. \& Yang, J. Spatiotemporal regulation of epithelialmesenchymal transition is essential for squamous cell carcinoma metastasis. Cancer Cell 2012;22:725-736.

Umeda T, Ishida M, Murata S, Mori T, Kawai Y, Itoi N, Tomida K, Tanaka A, Sakai S, Kitamura M, Kubota Y, Kushima R, Tani M. Immunohistochemical analyses of CD44 variant isoforms in invasive micropapillary carcinoma of the breast: comparison with a concurrent conventional invasive carcinoma of no special type component. Breast Cancer 2015;23:869875.

Vermeulen L, de Sousa e Melo F, Richel DJ, Medema, JP. The developing cancer stem-cell model: clinical challenges and opportunities. Lancet Oncol. 2012;13:e83-e89.

Visvader JE, Lindeman GJ. Cancer stem cells in solid tumours: accumulating evidence and unresolved questions. Nat. Rev. Cancer 2008;8:755-768.

Waclaw B, Bozic I, Pittman ME, Hruban RH, Vogelstein B, Nowak M. A Spatial model predicts dispersal and cell turnover cause reduced intra-tumor heterogeneity. Nature. 2015;525:261-7.

Wang P, Gao Q, Suo Z, Munthe E, Solberg S, Ma L, Wang M, Westerdaal NA, Kvalheim G, Gaudernack G. Identification and characterization of cells with cancer stem cell properties in human primary lung cancer cell lines. PLoS One 2013;8:e57020.

Wang Y, Lin Z, Sun L, Fan S, Huang Z, Zhang D, Yang Z, Li J, Chen W. Akt/Ezrin Tyr353/NF$\kappa \mathrm{B}$ pathway regulates EGF-induced EMT and metastasis in tongue squamous cell carcinoma. Br J Cancer. 2013;110:695-705.

Weinstein RS, Merk FB, Alroy J. The structure and function of intercellular junctions in cancer. Adv Cancer Res. 1976;23:23-89.

Welkoborsky HJ, Gluckman JL, Jacob R, Bernauer H, Mann W. Tumor biologic prognostic parameters in T1N0M0 squamous cell carcinoma of the oral cavity. Laryngorhinootologie. 1999;78:131-8. 
Wu S, Xue W, Huang X, Yu X, Luo M, Huang Y, Liu Y, Bi Z, Qiu X, Bai S. Distinct prognostic values of ALDH1 isoenzymes in breast cancer. Tumour Biol. 2015;36(4):2421-2426.

Yu M, Bardia A, Wittner BS, Stott SL, Smas ME, Ting DT, Isakoff SJ, Ciciliano JC, Wells MN, Shah AM, Concannon KF, Donaldson MC, Sequist LV, Brachtel E, Sgroi D, Baselga J,

Ramaswamy S, Toner M, Haber DA, Maheswaran S. Circulating breast tumor cells exhibit dynamic changes in epithelial and mesenchymal composition. Science. 2013;339(6119):580-4.

Zang S, Liu T, Shi J, Qiao L. Curcumin: a promising agent targeting cancer stem cells. Anticancer Agents Med Chem. 2014;14:787-92.

Zhou C, Sun B. The prognostic role of the cancer stem cell marker aldehyde dehydrogenase 1 in head and neck squamous cell carcinomas: a meta-analysis. Oral Oncol 2014; 50: 1144-1148. 

ANNEX 



\section{ANNEXS}

\section{FACULDADE DE ODONTOLOGIA DE BAURU- USP}

\section{PARECER CONSUBSTANCIADO DO CEP}

\section{DADOS DO PROJETO DE PESQUISA}

Título da Pesquisa: Análise imuno-histoquímica diferencial e comparativa entre CEC de boca primário e lesões metastáticas correspondentes

Pesquisador: Camila de Oliveira Rodini Pegoraro

Área Temática:

Versão: 1

CAAE: 50695815.2 .0000 .5417

Instituição Proponente: Faculdade de Odontologia de Bauru

Patrocinador Principal: FUNDACAO DE AMPARO A PESQUISA DO ESTADO DE SAO PAULO

\section{DADOS DO PARECER}

Número do Parecer: 1.339 .642

\section{Apresentação do Projeto:}

Projeto de dissertação de mestrado intitulado "Análise imuno-histoquímica diferencial e comparativa entre CEC de boca primário e lesões matastáticas correspondentes" de Rafael Carneiro Ortiz sob orientação da Profa. Dra. Camila de Oliveira Rodini Pegoraro. Serão utilizadas 195 amostras teciduais parafinadas de lesões primárias e linfonodos correspondentes de pacientes com CEC de boca, constituintes de material de arquivo

devidamente legalizado e com todos os Termos de Consentimento Livre e Esclarecido armazenados. O material será procedente do Laboratório de Anatomopatologia do Hospital das Clínicas (HC) da Faculdade de Medicina da USP. A pesquisa já foi aprovada pela Comissão de Ética para Análise de Projetos de Pesquisa da FMUSP. Serão incluídos casos de pacientes com idade igual ou superior a 40 anos e tabagistas que apresentarem lesões em cavidade oral, em especial língua e assoalho bucal (C01-02), que foram apenas submetidos à ressecção cirúrgica do tumor primário e de linfonodos cervicais. A técnica de imuno-histoquímica será utilizada para a avaliação da co-expressão e distribuição de marcadores relacionados com o fenótipo de CSC (CD44, p75NGFR, BMI-1 e ALDH1) bem como de células em TEM(vimentina, Snail, AxL, Twist, N-cadherina, E-cadherina).Os blocos parafinados serão seccionados $(3 \mathrm{~m})$ em micrótomo e os cortes colocados sobre lâminas de vidro previamente silanizadas $(3-$

Endereço: DOUTOR OCTAVIO PINHEIRO BRISOLLA 75 QUADRA 9

Bairro: VILA NOVA CIDADE UNIVERSITARIA CEP: $17.012-901$

UF: SP Município: BAURU

Telefone: (14)3235-8356 Fax: (14)3235-8356 E-mail: cep@fob.usp.br 


\section{FACULDADE DE ODONTOLOGIA DE BAURU- USP

Continuação do Parecer: 1.339 .642

aminopropyiltriethoxysilano a 10\%, em etanol absoluto). Os procedimentos laboratoriais para realização da técnica imuno-histoquímica serão realizados no Laboratório de Histologia do Departamento de Ciências Biológicas da Faculdade de Odontologia de Bauru da Universidade de São Paulo (FOB/USP. Será utilizado o método do polímero marcado (EnvisionTM), com os anticorpos primários para as proteínas CD44, p75NGFR, BMI-1, ALDH1, vimentina, Snail, AxL, Twist, N-caderina e E-caderina. Inicialmente, os cortes serão desparafinizados por imersão em xilol e hidratados em porcentagens decrescentes de etanol, seguido de incubação em peróxido de hidrogênio $3 \%$

diluído em PBS, por 40 minutos. Após exposição antigênica, que poderá ser por meio de solução de tampão Citrato $10 \mathrm{mM} \mathrm{pH} \mathrm{6,0,} \mathrm{EDTA} 1 \mathrm{mM} \mathrm{pH} \mathrm{8,0} \mathrm{ou} \mathrm{Tris-EDTA} \mathrm{(10} \mathrm{mM} \mathrm{Tris,} 1 \mathrm{mM}$ EDTA) pH 9,0 em steamer a $95^{\circ} \mathrm{C}$ durante 20 minutos, conforme padronização, os cortes serão incubados por 30 minutos em BSA 5\%/PBS (Phosphate Buffered Saline) acrescido de Triton 0,5\% para bloqueio de sítios inespecíficos e posterior incubação com o anticorpo primário em câmara úmida $4^{\circ} \mathrm{C}$. Em seguida será feita incubação do sistema EnVision ${ }^{T M}$ Dual Link System HRP por 30 minutos. A revelação da reação será feita com 3,3'diaminobenzidina e as lâminas serão contra-coradas com hematoxilina de Meyer. Entre essas passagens os cortes serão lavados 2 vezes com solução tampão PBS pH 7,4 acrescido de Triton 0,1\%. Os cortes serão então desidratados em cadeia de álcool ascendente por 5 min cada, nas concentrações (\%) de 50, 60, 70, 80, 90, 95, absoluto(1), absoluto (2), absoluto (3), e diafinizados em dois banhos de xilol. As lâminas serão então montadas em resina Permount para exame ao microscópio de luz. A fim de se observar marcação específica das proteínas, as reações serão previamente padronizadas em amostras controle de tecido humano parafinadas com reatividade conhecidamente positiva para cada anticorpo, funcionando como controle externo positivo da reação. Como controle interno negativo, será utilizado o mesmo tecido, onde o anticorpo primário foi substituído por soro,devendo a reação ser completamente negativa.

\section{Objetivo da Pesquisa:}

O objetivo geral do projeto proposto é analisar a presença e distribuição tecidual de marcadores CSC, assim como do fenômeno de TEM, em CEC de boca, bem como correlacionar os achados microscópicos com fatores clinicopatológicos e prognósticos, contribuindo para a compreensão do comportamento biológico das células tumorais com capacidade de mobilidade, invasão e disseminação.

\section{Avaliação dos Riscos e Benefícios:}

Riscos: A presente pesquisa utilizará material de arquivo referente a biópsias de amostras

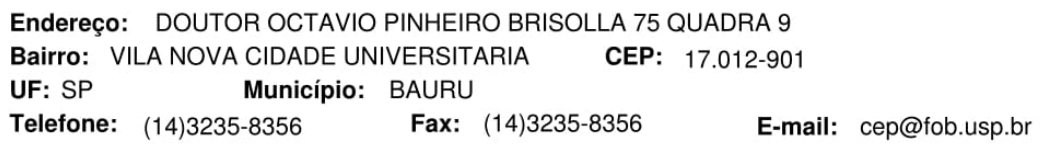




\section{FACULDADE DE ODONTOLOGIA DE BAURU- USP}

Continuaçāo do Parecer: 1.339 .642

teciduais parafinadas de lesões prmárias e linfonodos correspondentes. Portanto, seu uso não envolve quaisquer riscos.

Benefícios: A principal contribuição científica da proposta é ampliar o conhecimento das características moleculares do carcinoma epidermóide de boca, bem como indicar que aquelas células tumorais capazes de invadir o tecido subjacente e gerar metástases tenham o fenótipo de CSC e sofreram o processo de TEM, viabilizando a utilização de biomarcadores dessas subpopulações como preditores de prognóstico e valor terapêutico. O presente

trabalho visa contribuir na compreensão dos eventos envolvidos na formação e progressão do CEC de boca a partir da expressão diferencial de marcadores de TEM e células-tronco de câncer. Além disso, após a correlação dos dados de expressão com os clínico-patológicos e de sobrevida, espera-se contribuir para a identificação de quais pacientes devem ser seguidos com maior atenção e/ou submetidos a terapias adjuvantes.

\section{Comentários e Considerações sobre a Pesquisa:}

Trata-se de um projeto de dissertação de mestrado de análise imuno-histoquímica utilizando-se amostras teciduais parafinadas (material de arquivo) de lesões primárias e linfonodos correspondentes.

\section{Considerações sobre os Termos de apresentação obrigatória:}

Todos os Termos Obrigatórios foram apresentados além de parecer da Comissão de Ética para análise de Projetos de Pesquisa da FMUSP.

\section{Recomendações:}

Sem recomendações

Conclusões ou Pendências e Lista de Inadequações:

Sem pendências

\section{Considerações Finais a critério do CEP:}

Esse projeto foi considerado APROVADO na reunião ordinária do CEP de 18.11.2015, com base nas normas éticas da Resolução CNS 466/12. Ao término da pesquisa o CEP-FOB/USP exige a apresentação de relatório final. Os relatórios parciais deverão estar de acordo com o cronograma e/ou parecer emitido pelo CEP. Alterações na metodologia, título, inclusão ou exclusão de autores, cronograma e quaisquer outras mudanças que sejam significativas deverão ser previamente comunicadas a este CEP sob risco de não aprovação do relatório final. Quando da apresentação deste, deverão ser incluídos todos os TCLEs e/ou termos de doação assinados e rubricados, se pertinentes.

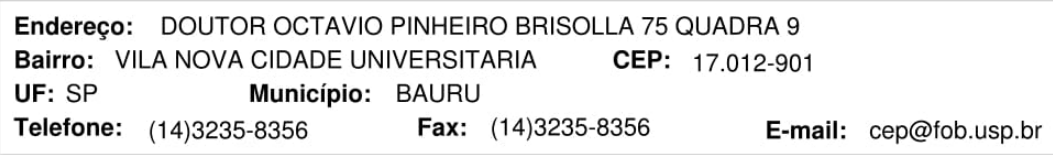




\section{FACULDADE DE ODONTOLOGIA DE BAURU- USP}

Continuação do Parecer: 1.339.642

Este parecer foi elaborado baseado nos documentos abaixo relacionados:

\begin{tabular}{|c|c|c|c|c|}
\hline Tipo Documento & Arquivo & Postagem & Autor & Situação \\
\hline $\begin{array}{l}\text { Informações Básicas } \\
\text { do Projeto }\end{array}$ & $\begin{array}{l}\text { PB_INFORMAÇÓES_BÁSICAS_DO_P } \\
\text { ROJETO 612843.pdf }\end{array}$ & $\begin{array}{c}28 / 10 / 2015 \\
16: 30: 55\end{array}$ & & Aceito \\
\hline $\begin{array}{l}\text { Projeto Detalhado / } \\
\text { Brochura } \\
\text { Investigador }\end{array}$ & Projeto_CEP.pdf & $\begin{array}{c}28 / 10 / 2015 \\
16: 29: 23\end{array}$ & Rafael Carneiro Ortiz & Aceito \\
\hline Outros & $\begin{array}{l}\text { Alteracao_Responsabilidade_Projeto_Pr } \\
\text { incipal.jpg }\end{array}$ & $\begin{array}{c}28 / 10 / 2015 \\
16: 20: 40\end{array}$ & Rafael Carneiro Ortiz & Aceito \\
\hline Outros & Aprovacao_CAPPesq_Subprojeto_2.pdf & $\begin{array}{l}28 / 10 / 2015 \\
16: 19: 53\end{array}$ & Rafael Carn & Aceito \\
\hline Outros & Aprovacao_CAPPesq_Subprojeto_1.pdf & $\begin{array}{c}28 / 10 / 2015 \\
16: 17: 53\end{array}$ & Rafael Carneiro Ortiz & Aceito \\
\hline Outros & $\begin{array}{l}\text { Aprovacao_CAPPesq_Projeto_Principal. } \\
\text { pdf }\end{array}$ & $\begin{array}{c}28 / 10 / 2015 \\
16: 11: 49\end{array}$ & Rafael Carneiro Ortiz & Aceito \\
\hline \begin{tabular}{|l} 
Declaração de \\
Instituição e \\
Infraestrutura \\
\end{tabular} & $\begin{array}{l}\text { Carta_Encaminhamento_Termo_Aquies } \\
\text { cencia.pdf }\end{array}$ & $\begin{array}{c}28 / 10 / 2015 \\
15: 30: 21\end{array}$ & Rafael Carneiro Ortiz & Aceito \\
\hline Outros & Questionario.pdf & $\begin{array}{c}28 / 10 / 2015 \\
15: 11: 54\end{array}$ & Rafael Carneiro Ortiz & Aceito \\
\hline Outros & Declaracao_FAPESP.pdf & $\begin{array}{c}28 / 10 / 2015 \\
14: 58: 51 \\
\end{array}$ & Rafael Carneiro Ortiz & Aceito \\
\hline \begin{tabular}{|l} 
Declaração de \\
Pesquisadores
\end{tabular} & Declaracao_Compromisso.pdf & $\begin{array}{c}28 / 10 / 2015 \\
14: 57: 49\end{array}$ & Rafael Carneiro Ortiz & Aceito \\
\hline Folha de Rosto & Folha_de_Rosto.pdf & $\begin{array}{c}28 / 10 / 2015 \\
14: 55: 25\end{array}$ & Rafael Carneiro Ortiz & Aceito \\
\hline
\end{tabular}

Situação do Parecer:

Aprovado

Necessita Apreciação da CONEP:

Não

BAURU, 26 de Novembro de 2015

\section{Assinado por:}

Izabel Regina Fischer Rubira Bullen

(Coordenador)

\footnotetext{
Endereço: DOUTOR OCTAVIO PINHEIRO BRISOLLA 75 QUADRA 9

Bairro: VILA NOVA CIDADE UNIVERSITARIA CEP: $17.012-901$

UF: SP

Município: BAURU

Telefone: (14)3235-8356

Fax: (14)3235-8356

E-mail: cep@fob.usp.br
} 


\section{USP - FACULDADE DE ODONTOLOGIA DE BAURU DA. USP}

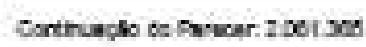

apenas 137 questionarios de forma retrosectva selechorados dentre o periodo de agosio de 2012 a juho de 2016 comespondente ao periodo de instalaçbo do PET-CT na chica COW-Eauru.

objattwo da Notincagis:

Aprecentar o relatoro thal da pesquse regstrada sob o n. CAE: 30150014.4 .0000 .8417

Avallaço dos Fuscos a Beneficloe:

Fiscos:

Segundo as pesqulsadoras a pesquisa nto oferece riscos acs paclentes, visto que sera felto somente analse dos exanes que constam de materlal de ampuo da cinca de medana nucear (CDW). Logo, o riso pode ser considerado inprovavel, pots nesle tpo de estudo sab avaladas magens que ja foran outdas.

Benetiocs

Esperar se mehorar o dagntsto do cancer de cabepa e pesoxpo por melo da aplcacto do exame PET-CT. Conirbuindo aseln, para um mehar desempenho ro prognostco da doenga

Comentarlos e Consldersges aobre a wotincaga:

Apresentacto de un relatoro ina.

Consideracose edore os Tormos de apreesntapso obrigatorla:

Fol apresentado apenss o reatdrio inal da pesqusa com os resulados e conclusbes.

Recomendagber:

Nob se apilca.

Concluses ou Pendinclas e Lata de Inadequages:

Trata-se de um relatoro final de un projeto inttulado "importancla da PETicT cono metodo auxilar de dlagncatico nos tumores da regdo de cabega e pescopo Estudo na doade de Eaunser, de autorta de Tuana Canso Mederos e onentaço da Profa. Dra. Ana Lucla Alvarez Capeloza. As pequlisadorss tambem contaram com a coaboractio do Dr. Fatlo Marins silva responsavel pela Clnca de Wedicina Nuclear (CDM) de Baur que autorizou a pesqusadora a tazer laso dos dados arqulvados na cinica de sua resonsab idade. As pesqulsadoras trabaharam apenas com dados coletados que estavam arquvados na referida dinca acima diada. Os dados colelados sto referentes a exames com dagnostcos de cancer de cabepa e pescoso, especificamente o PET-CT (Siemens). Inkalmente o grupo amostral seria de 150 exames abrangeno todos os tpos de canceres de cabepa e pescopo ben como seu grau de estadlamerto. Entretanto, as pesqusadoras relataram que foram avalados apenas 137 questionarios de forma retrospectva seleclonados

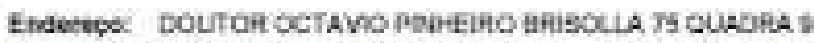

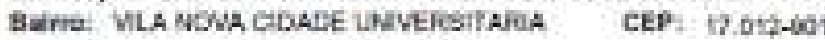

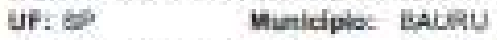

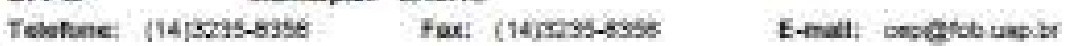




\section{USP - FACULDADE DE ODONTOLOGIA DE BAURU DA USP}

Cothugh soment 2 weins

dexre o periodo de agosto de 2012 a juho de 2016 comespondentes ao pericob de histalagto do PET-CT na cinka CDM-Eauru As pesqulsadoras nos apresentaram um relatoro final com as concusbes e resultados de sua pesqusa. Chenat se que a pesqusa fol reallada contome aprovada por este cep, razbo pela qual sou de parecer pela aprovaço do relatorio fina apresentado.

Considerapoea finala a chterio do cep:

O CEP reunido ordinarlamente no da 10.06.2017 acala por unanimidade o parecer APROVADO, enitido pelo relator, score o réatoro ina da pesquisa.

Este parecer fol etaborado baseado nos documentoe abatxo relacionados:

\begin{tabular}{|c|c|c|c|c|}
\hline Tpo Documento & Arquoro & Postagen & Autor & Sthacha \\
\hline $\begin{array}{l}\text { Envio de Relatorlo } \\
\text { Fina }\end{array}$ & relatoro_tnal_ceppoff & $\begin{array}{c}26042017 \\
0614: 40\end{array}$ & $\begin{array}{l}\text { TLana Canses } \\
\text { Mederos: }\end{array}$ & Acelto \\
\hline
\end{tabular}

stuagso do Paracer:

Aprovado

Nocesita Aproclaço da coneP:

No

EAURul 12 de Malo de 2017

Assinado por.

Ana Lucia Pompdia Fraga do Aimalda

(Coordenador)

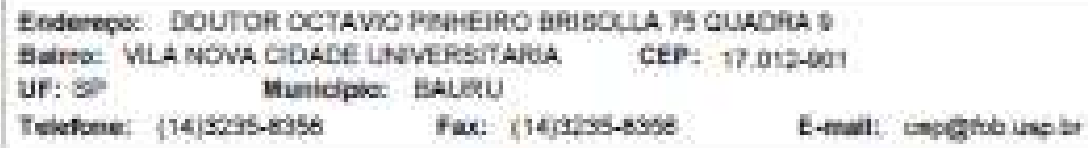

